\title{
Vivianite formation as indicator of human impact in porous sediments
}

\author{
Csámer Árpád ${ }^{1} \cdot$ Papp Lajos ${ }^{2} \cdot$ Kristály Ferenc $^{3} \cdot$ Szakáll Sándor $^{3} \cdot$ Rózsa Péter $^{1}[$
}

Received: 5 August 2020 / Accepted: 30 July 2021 / Published online: 16 August 2021

(c) The Author(s) 2021

\begin{abstract}
Environmental geological survey of a chemical works situated in NE Hungary has been performed for decades. Up till now, several hundreds of drillings of different depths as well as engineering geological soundings have been carried out in the area. Vivianite has been found in a discrete part of a drilling in a gray, silty bed at the depth $6.8-8.5 \mathrm{~m}$. Vivianite was analyzed using X-ray powder diffraction (XRPD), thermal analysis (TG/DTG), and scanning electron microscopic and energy dispersive spectrometry (SEM-EDS) techniques. To demonstrate the spatial distribution of hydrochemical parameters and selected chemical constituents the available data concerning drillings and hydrochemical analyses were collected and evaluated, and field measurements were also performed. For mapping the distribution of relevant physico-chemical parameters and chemical constituents kriging interpolation method was used. Archive aerial photographs demonstrate that a coffered, earth-bedded reservoir for storing huge amounts of extracted plant debris is situated in the vicinity of the drilling. Our study suggests that orthophosphate derived from decomposing biomass entered the groundwater and accumulated within the lowest permeability zone of the intact bedrock. Therefore, the discrete appearance of vivianite in the drilling can be regarded, at least partly, the result of a man-induced mineralogical process.
\end{abstract}

Keywords Vivanite $\cdot$ Groundwater $\cdot$ Organic debris $\cdot$ Orthophosphate release $\cdot$ Human-induced mineralization

\section{Introduction}

Vivianite is a hydrous ferrous iron phosphate mineral $\left[\mathrm{Fe}_{3}\left(\mathrm{PO}_{4}\right)_{2} \cdot 8 \mathrm{H}_{2} \mathrm{O}\right]$ named after John Henry Vivian (1785-1855), an English mineralogist, by Abraham Gottlob Werner (1749-1817). It crystallizes in the monoclinic system in the form of needle-shaped crystals or spherical aggregates with sizes ranging from some micrometers to some centimeters. In its original state vivianite is colorless, however, due to gradual oxidization of ferrous iron, it turns to vivid blue in air. When values of ferric iron exceed $50 \%$ vivianite will alter to metavivianite $\left[\mathrm{Fe}^{2+} \mathrm{Fe}^{3+}{ }_{2}\left(\mathrm{PO}_{4}\right)_{2}(\mathrm{OH})_{2} \cdot 6 \mathrm{H}_{2} \mathrm{O}\right]$ (Rouzies and Millet 1993). At higher temperatures further oxidization may result in the formation of ferric phosphate minerals,

Rózsa Péter

rozsa.peter@science.unideb.hu

1 Department of Mineralogy and Geology, University of Debrecen, Egyetem tér 1., Debrecen 4032, Hungary

2 Terrapeuta Ltd., Táncsics Mihály utca 17/1., Debrecen 4028, Hungary

3 Department of Mineralogy and Petrography, University of Miskolc, Miskolc-Egyetemváros 3515, Hungary for example lipscombite $\left[\left(\mathrm{Fe}^{2+}, \mathrm{Mn}^{2+}\right)\left(\mathrm{Fe}^{3+}\right)_{2}\left(\mathrm{PO}_{4}\right)_{2}(\mathrm{OH})_{2}\right]$, rockbridgeite $\left[\mathrm{Fe}^{2+} \mathrm{Fe}^{3+}{ }_{4}\left(\mathrm{PO}_{4}\right)_{3}(\mathrm{OH})_{5}\right]$ and strengite $\left(\mathrm{FePO}_{4} \cdot 2 \mathrm{H}_{2} \mathrm{O}\right)$ (Nriagu and Dell 1974).

Vivianite may occur in different geological environments. Its formation requires reducing conditions with high ferric iron and orthophosphate as well as very low $\mathrm{S}^{2-}$ concentrations in the solution (Nriagu 1972). Vivianite can be formed as a secondary mineral in the oxidation zone of ore deposits, and it may precipitate in sediments under reducing conditions in fluvial, lacustrine, marine and estuarine environments, and waterlogged soils (Rothe et al. 2016; Grizelj et al. 2017). Moreover, it can be found in organic-rich, highly contaminated canal beds (Dodd et al. 2000, 2003; Taylor and Boult, 2007), in wastewater sludge (Frossard et al. 1997) as well as in archeological settings (McGowan and Prangnell 2006). Since increased nutrient supply is favorable for vivianite authigenesis, its occurrence in sedimentary settings may indicate human impact (Goslar et al. 1999).

Since vivianite is stable under reducing conditions, the phosphorus bound in its crystal structure. Consequently, eutrophication of freshwaters due to human activities could be controlled using Fe salts for removing significant amount of phosphorus from the water through vivianite formation 
(Gunnars et al. 2002; Gächter and Müller 2003; Kleeberg et al. 2012; Rothe et al. 2014; O'Connell et al. 2015). Similarly, by the formation of iron(II) phosphate minerals, ferric iron amendments may also increase phosphorus retention in wastewater-treating constructed wetlands (Vymazal 2007) and in septic tank wastewaters (Azam and Finneran 2014).

It seems that vivianite may play important role in controlling arsenic release in groundwater environments. Some experiments suggest that vivianite can adsorb dissolved arsenic(V) (Islam et al. 2007; Hudson-Edwards et al. 2008; Thinnappan et al. 2008), and others found that arsenate(V) can partly replace the phosphate anion forming a vivianite-symplesite $\left[\mathrm{Fe}_{3}\left(\mathrm{PO}_{4}\right)_{1.7}\left(\mathrm{AsO}_{4}\right)_{0.3} \cdot 8 \mathrm{H}_{2} \mathrm{O}\right]$ solid solution (Muehe et al. 2016).

In Hungary, vivianite occurs in several localities of different geological settings (Szakáll et al. 2005). It can be found in close vicinity of iron ore bodies (Rudabánya, NE Hungary), recent or former swampy areas together with bog iron (Somogyszob, South Transdanubian region; Nyírség, East Hungary; Bagamér and Létavértes villages at the Hungarian-Romanian border; Fertó Lake at the Austrian-Hungarian border), in oil shale from the Little Hungarian Plain as well as in clays mainly in the Great Hungarian Plain.

The study area is situated in the central part of a chemical plan. The environmental geological survey was begun before 2000; and, up till now, several hundred drillings of different depth and engineering geological sounding have been made. Most of the drillings are shallower than $15 \mathrm{~m}$ (although some drillings exceed the depth of $30 \mathrm{~m}$ ), and several dozen ones reach $8 \mathrm{~m}$ in depth. In the cores there is no vivianite detectable by the naked eye, or only some traces can be noticed. However, in 2007 the occurrence of vivianite was observed in a discrete part of clustered monitoring wells No. ICE-113 drilled in the central part of the area of the chemical works. The drilled clayey-silty layers contain numerous vivianite aggregates of some millimeters in size at 7.6-8.5 m depth from the surface. Archive aerial photograph in Fig. 1 shows that next to the site of monitoring well cluster No. ICE-113 an earth-bedded sewage pond with the size of approximately
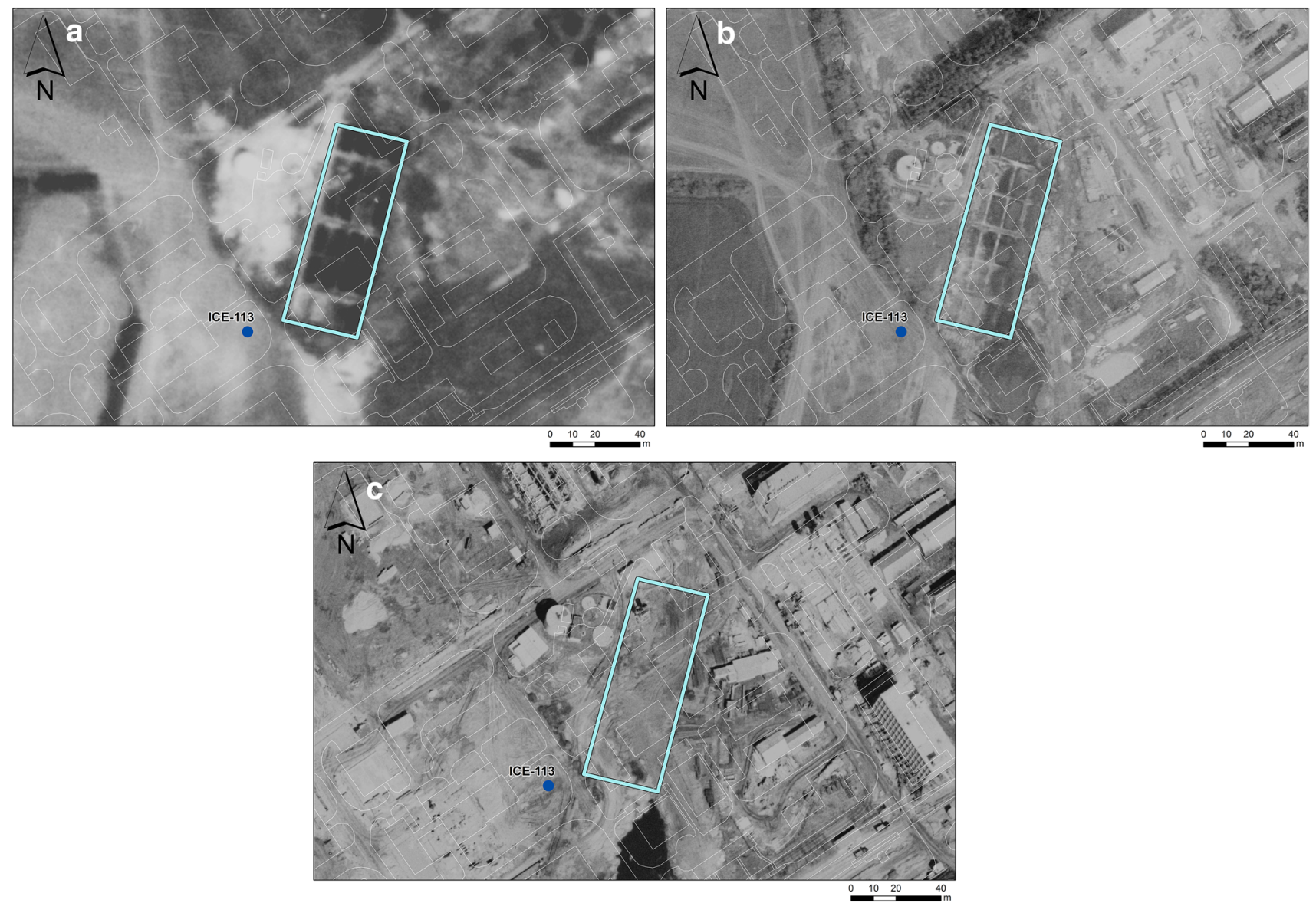

Fig. 1 a Pond (blue line) for disposal of plant waste coming from extraction and its environments on aerial photographs taken in 1956. b Contour of the pond and the cassettes are still recognizable on the aerial photograph taken in 1965. c The ponds and the cassettes are no longer visible on the aerial photograph taken in 1967. b and $\mathbf{c}$ available from fentrol.hu. 
$30 \times 12 \mathrm{~m}$ had been formed where plant waste coming from the technological process had been disposed of. There is hardly any information on the date of the building and the depth of the pond, and the quantity of the plant material has not been known, either. It can be seen on aerial photos taken in 1956 (Fig. 1a) and its contour and the cassettes can be noticed on an aerial photo taken in 1965 (Fig. 1b). However, it no longer visible on the aerial photo taken in 1967 (Fig. 1c); the sewage pond was filled up, covered with concrete, and different containers and tanks were deposited on the site. The aim of this study was to reveal factors (both natural and anthropogenic) that play a key role in the formation of this distinct vivianite occurrence.

\section{Geological settings}

Quaternary geological history of the Great Hungarian Plain, the largest landscape unit of Hungary, has been basically determined by two geological events. The first is the formation of the Pannonian Basin in a structural sense at the end of the Miocene. This relatively young basin (around 15 million years old) has an anomalous thin lithosphere and is filled with several thousand meters thick sediment layers; simultaneous to their accumulation intense volcanism took place as late as the Quaternary (Jámbor 2001; Zelenka et al. 2004; Harangi, 2001; Balázs et al. 2016). Geological development of the Pannonian Basin was in close relationship with that of the Central Paratethys (middle part of the Paratethys extending from the northern foreland of the Alps to the Aral Lake). Its final occlusion from the ocean resulted in a peculiar endemic fauna. Rivers coming from the surrounding mountainous area formed huge delta systems, and 4.5-6.5 mys BP the Pannonian Lake, a remnant of the Paratethys was filled with prograding delta sediments; the area became a fluvial plain with several small lakes (Kázmér 1990; Gábris and Nádor 2007).

The second is the fact that the area of the Great Hungarian Plain belonged to the periglacial area, where one of the most complex fluvial systems in Europe developed under the given climatic conditions (Rónai 1985; Jámbor 2001; Nádor et al. 2007; Kiss et al. 2015). The Danube and the Tisza, the two main rivers of the Great Hungarian Plain, and their tributaries formed alluvial plains and fans, where large areas were covered with loess and loess derivatives transported by strong wind from different source areas (Lehmkuhl et al. 2018). Simultaneously, wind-blown sand and mixed sediments of sand and loess coming from local fluvial sources were also formed (Rónai 1985).

The study area is situated in the border area of Hortobágy and Hajdúság regions, which are lowland terrains of recent and young sedimentary deposits (Fig. 2). The western part of the site belongs to Hortobágy plain with a height of $90 \mathrm{~m}$ a.s.l., and the eastern part to the loessy ridge of Hajdúság has an elevation of $120-150 \mathrm{~m}$ a.s.l. The biggest watercourse in the region is the Tisza River.

On and near the surface there are dominantly fluvial, subordinately eolian and lacustrine Pleistocene and Holocene sedimentary formations. Consequently, these sediments have a quite complex structure with highly varying lithologic character, thickness, extension, and, due to the fluvial environment, interfingering and wedging of the strata.

The thickness of the Quaternary formations accumulated on the Pannonian strata ranges from 125 to $160 \mathrm{~m}$ (Franyó 1992). This dominantly fluvial sediment formation is wellbedded; its lower part is dominated by gravel and sand layers with interbedded clayey layers, and its upper part is characterized by fine-grained sediments, i.e. sand-silt-clay layers and interbeddings (Rónai and Moldvay 1966).

The oldest formations on the surface (loess, loess derivative, fluvial sandy gravel, gravel, and eolian sand) were deposited in the Late Pleistocene. In the Hortobágy area, which is situated at a lower altitude, fluvial silt and clayey silt as well as fluvial clay, silt and lacustrine clayey silt settled in the Old and the New Holocene, respectively. Salinization is common, and it may occur in almost every sediment type.

Geological features of the study area can be summarized as it follows. In the industrial area, highly cohesive loamy-clayey solonetz is the dominant soil type with a maximum thickness of $1 \mathrm{~m}$. The original Holocene soil occurs only in smaller or larger patches, it is changed by anthropogenic landfill of varying composition and thickness. Beneath the soil, there is a $1-3 \mathrm{~m}$ thick fine-silty coarse silt layer with varying clay content (loess derivative). It is friable above the level of the water table, and plastic beneath it. The loess derivative was deposited on gray or yellow finegrained sand, silty fine sand, which is the first groundwater aquifer. Here and there the proportion of silt is significant, and the sediment should be regarded as fine sandy silt. It is not a horizontal formation therefore it can be pitched out. Its thickness ranges from 1 to $2.5 \mathrm{~m}$.

Beneath this aquifer, there is a cohesive clayey fine silt ("basal clay" or "underlying clay") layer with a thickness ranging from 1.5 to $4 \mathrm{~m}$. Considering sedimentary facies, it can be regarded as a floodplain deposit, however, the upper part of the "basal clay" proved to be fat clay based on soil mechanics consistency tests; therefore, it can be interpreted as an aquitard layer.

Beneath the "basal clay" gray or brown alternating finelayered fine sandy silt and silty sand layers with varying clay content can be found, the thickness of this formation is $12-15 \mathrm{~m}$. It can be interpreted as a floodplain deposit interfingering with levee sandy deposits.

The next formation extends down to $35 \mathrm{~m}$. It is built up with fine- and coarse-grained channel deposits alternating 

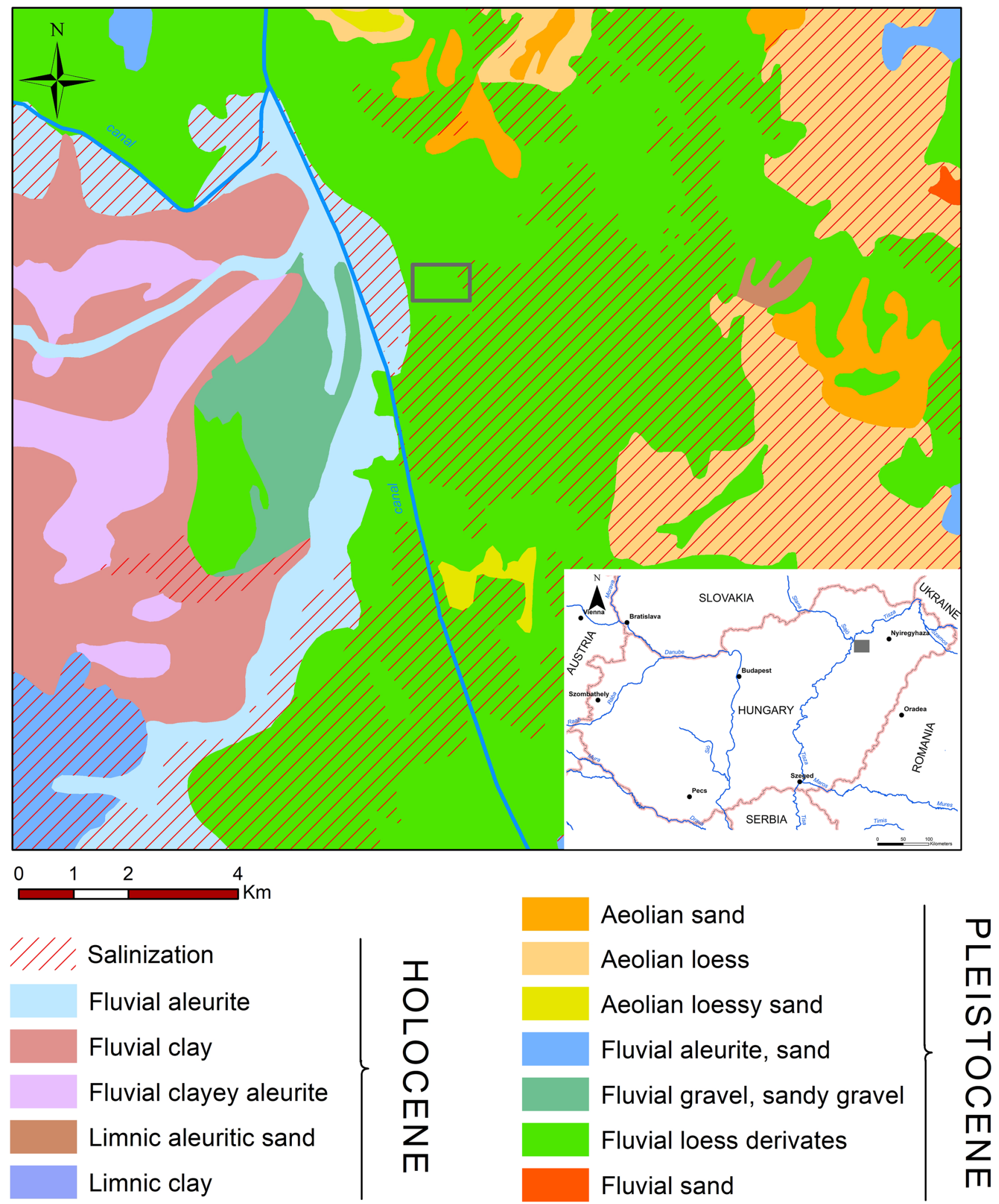

Fig. 2 Simplified geological map of the study area based on 1:100,000 surface geological map series of Hungary (https://map.mbfsz.gov.hu/ fdt100/) 
with bluish gray, highly carbonaceous alluvial silts and clays deposited in a dead water environment.

The potentiometric contour map based on synchronous hydraulic head data suggests that the horizontal flow of the groundwater in the first aquifer has a dominantly western direction (from 2 to $6 \mathrm{~m}$ ) (Fig. 3). Using HydrogeoEstimatorXL Excel-based tool (Devlin and Schillig 2017) the estimated mean horizontal hydraulic gradient is 0.004 for the first aquifer. The potentiometric contour map based on synchronous hydraulic head data measured in the second aquifer shows a simpler flow pattern and indicates a characteristic western flow direction. The value of the mean horizontal hydraulic gradient estimated using HydrogeoEstimatorXL (Devlin and Schillig 2017) for the second aquifer is 0.003 . The vertical hydraulic gradient between the first and second aquifers varies between -0.02 and -0.06 .

\section{Methods}

Soil samples of the underlying clay bed were taken from the cutting of the drilling of well cluster No. ICE-113 from various depths. Vivianite was separated manually under binocular stereomicroscope for X-ray powder diffraction (XRPD), thermal analysis (TG/DTG), and scanning electron microscopic and energy dispersive spectrometry (SEM-EDS) study.

Sieve and hydrometer analyses were combined to define the grain-size distribution of seven soil samples derived from well cluster No. ICE-113 drilling (4.0-4.25, 6.5-6.6, 7.6-7.8, 7.8-8.0, 8.0-8.2, 8.2-8.4, 8.4-8.5 m).

To identify the mineralogical composition of the underlying clay layer, as well as the presence of vivianite, XRPD analysis was performed on soil samples derived from 4.0 to $4.25 \mathrm{~m}$ and $6.5-6.6 \mathrm{~m}$ and on separated vivianite from
7.6 to $8.5 \mathrm{~m}$ depth intervals. XRPD analysis was carried out on air-dried and pulverized soil samples at the Institute of Mineralogy and Geology, University of Miskolc. A Bruker D8 Advance type diffractometer was used in Bragg-Brentano geometry, equipped with $\mathrm{Cu}$ anode. During the measurement fixed slit system and a dynamic scintillation detector with secondary graphite monochromator were applied. The accelerating voltage and current were $40 \mathrm{kV}$ and $40 \mathrm{~mA}$, respectively. Identification of mineral phases was achieved using Search/Match option of DiffracPlus EVA. Quantitative determination of crystalline phases was performed by full pattern matching procedure of the DiffracPlus Basic Evaluation Package software (EVA 11, Release 2005).

Thermal analysis (thermogravimetry) of separated vivianite from 7.6 to $8.5 \mathrm{~m}$ depth interval was carried out at the Department of Mineralogy and Geology, University of Debrecen using a Mettler-Toledo TGA/SDTA 851e thermosmicrobalance equipment. Approximately $25 \mathrm{mg}$ of the vivianite sample was heated in an open ceramic crucible at a rate of $10.0{ }^{\circ} \mathrm{C} / \mathrm{min}$ up to $800{ }^{\circ} \mathrm{C}$ under static air atmospheric condition.

The morphology and chemical composition of vivianite was investigated by SEM-EDS. A JEOL JXA-8600 Superprobe unit equipped with three wavelength-dispersive spectrometers and an EDX silicon drift detector (SDD) was used. These examinations were carried out at the Institute of Mineralogy and Geology, University of Miskolc. For EDX measurements $20 \mathrm{kV}$ accelerating voltage was used, with a probe current of $20 \mathrm{nA}$.

To demonstrate the spatial distribution of hydrochemical parameters and selected chemical constituents, the available data concerning drillings and hydrochemical analyses were collected. Field measurements were performed by Terrapeuta Ltd. using Hanna Instruments HI-9828 Multiparameter
Fig. 3 Groundwater contour map and flow direction of the site showing the elevation of piezometric surface for the a first and $\mathbf{b}$ second aquifers during the autumn season of 2013
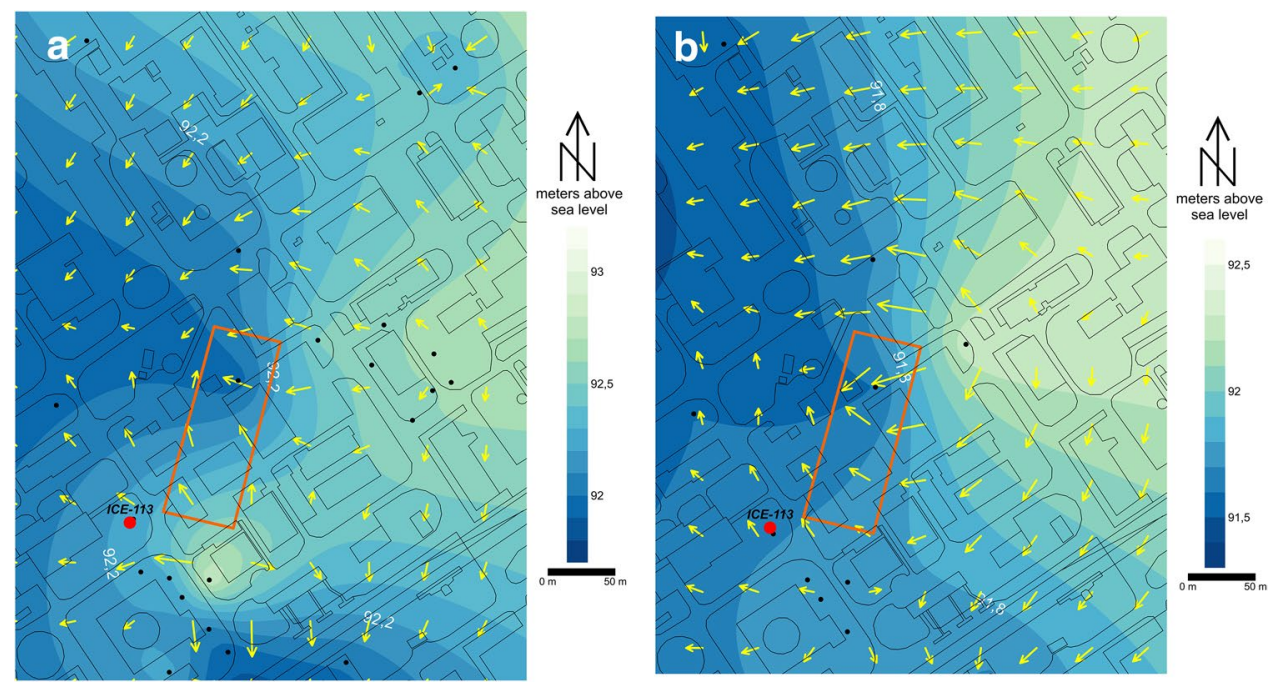
Portable Meter. For mapping the distribution of relevant data kriging interpolation method was used.

\section{Results}

Simplified stratigraphy of well cluster No. ICE-113 is shown in Fig. 4. Beneath the approximately $3 \mathrm{~m}$ thick mixed clayey-silty-sandy anthropogenic filling, there is a $1 \mathrm{~m}$ thick silt (loess derivatives) of brown color followed by a $4 \mathrm{~m}$ thick clayey formation containing vivianite of earthy appearance and bluish color at the depth ranging from 7.6 to $8.5 \mathrm{~m}$ showing aggregates of flattened crystals on a background consisting of quartz and phyllosilicates (Fig. 5). According to the drilling protocol, the vivianite-bearing layer was described as homogeneous, cohesive one of gray-grayish yellow color, which contains horizontally oriented carbonate concretions in considerable amounts. Detailed macroscopic

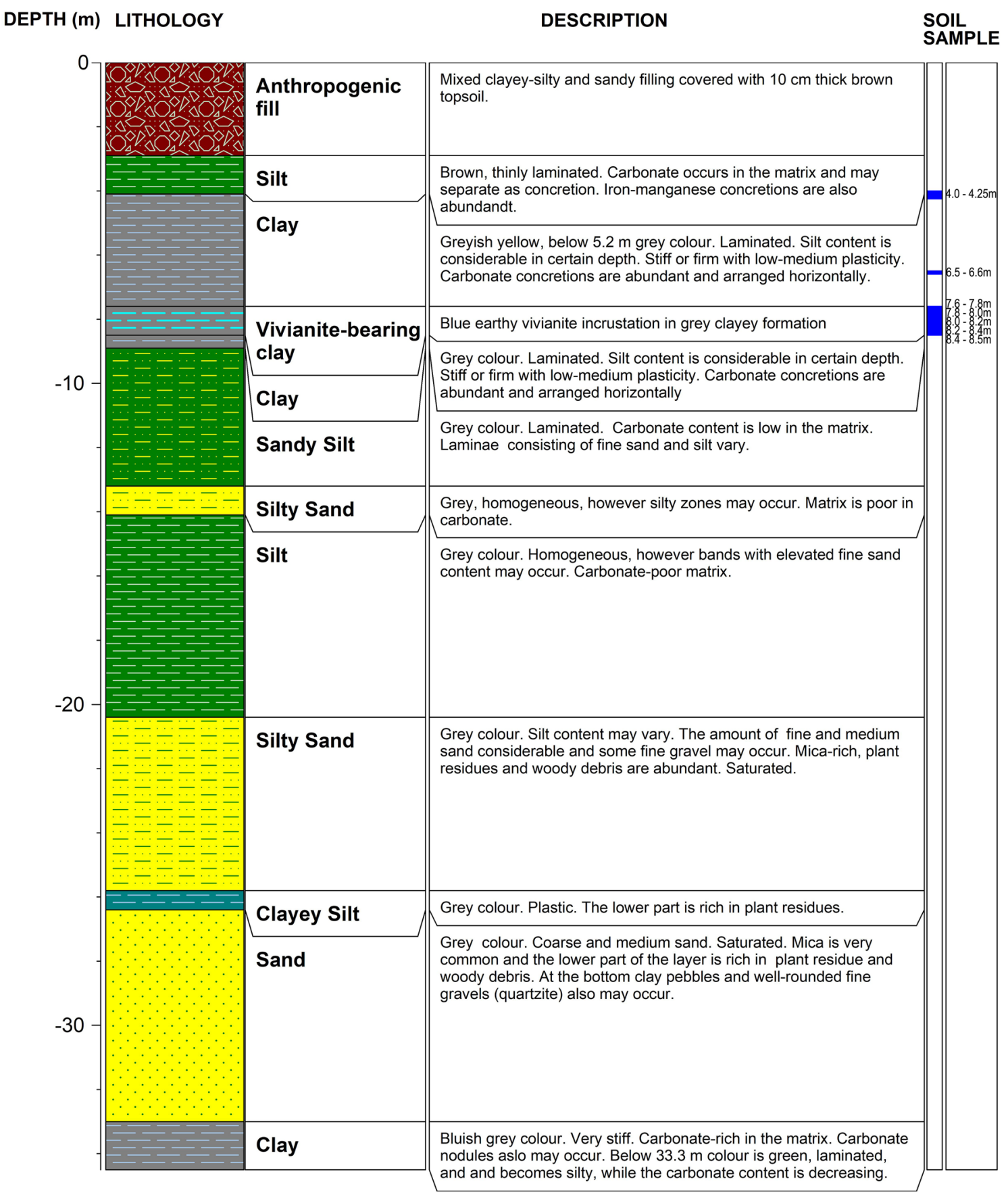

Fig. 4 Schematic geological setting of well cluster No. ICE-113 according to the drilling protocol 
observations and grain-size distribution analyses revealed, however, inhomogeneity of the clayey formation (Fig. 6; Table 1).

To the depth of $5.2 \mathrm{~m}$, it is light yellow clayey silt containing reddish black iron-manganese patches of some $\mathrm{mm}$ in size, fine micas, some carbonate in the matrix, and based on the results of the grain-size distribution (see
Table 1, No. ICE-113, 4.0-4.25 m), it can be regarded as clayey silt according to Shepard's nomenclature (Shepard 1954). XRPD and thermal analytical studies show that the mineral constituents of the layer are quartz (63\%), illite \pm muscovite $(19 \%)$, plagioclase $(13 \%)$, calcite $(3 \%)$ and chlorite (2\%) (Table 2).

Fig. 5 Macroscopic appearance and SEM photograph of vivianite from the cutting of well cluster No. ICE-113

Fig. 6 Field of grain-size distribution curves for seven samples of a "clay" layer in the section of $4.0-8.5 \mathrm{~m}$ of the well cluster No. ICE-113 (for data see Table 1)
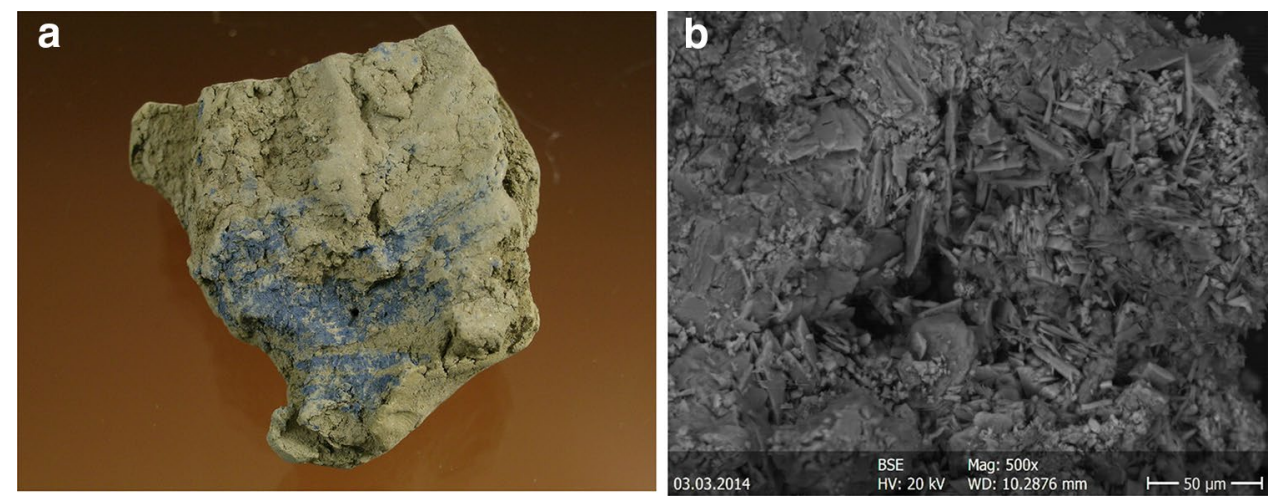

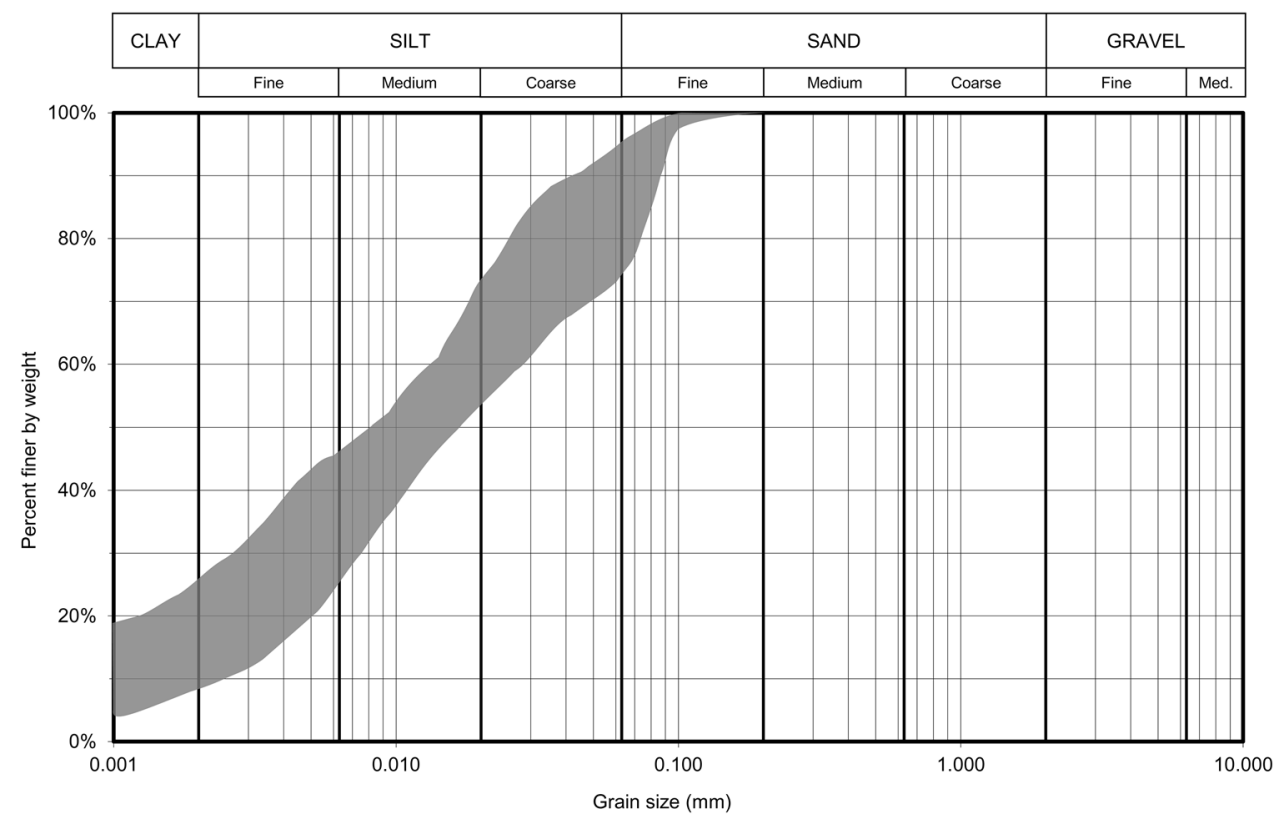

Table 1 Particle size distribution of the studied soil sample (dominant fraction in bold)

\begin{tabular}{llllccccc}
\hline Diameter $(\mathrm{mm})$ & Particle size fraction & \multicolumn{2}{l}{ ICE-113 samples } \\
\cline { 3 - 8 } & & $4.0-4.25 \mathrm{~m}$ & $6.5-6.6 \mathrm{~m}$ & $7.6-7.8 \mathrm{~m}$ & $7.8-8.0 \mathrm{~m}$ & $8.0-8.2 \mathrm{~m}$ & $8.2-8.4 \mathrm{~m}$ & $8.4-8.5 \mathrm{~m}$ \\
\hline $0.2-0.63$ & Medium sand & 3.87 & - & - & - & - & - \\
$0.063-0.2$ & Fine sand & 4.99 & 6.35 & 16.22 & 8.03 & 25.26 & 14.06 & 23.63 \\
$0.02-0.063$ & Coarse silt & 13.84 & 20.84 & 24.09 & 29.81 & 20.98 & 21.46 & 21.45 \\
$0.0063-0.02$ & Medium silt & 17.61 & $\mathbf{4 4 . 4 5}$ & $\mathbf{3 2 . 1 5}$ & $\mathbf{3 4 . 8 8}$ & $\mathbf{2 8 . 4 2}$ & $\mathbf{3 3 . 1 5}$ & $\mathbf{2 8 . 7 7}$ \\
$0.002-0.0063$ & Fine silt & 21.89 & 13.82 & 15.22 & 15.60 & 15.93 & 18.93 & 16.00 \\
$0.002<$ & Clay & $\mathbf{3 7 . 8 0}$ & 14.55 & 12.32 & 11.69 & 9.41 & 12.41 & 10.16 \\
\hline
\end{tabular}


Table 2 Results of XRPD

studies of the analyzed samples

\begin{tabular}{llllllll}
\hline Sample & Quartz & Plagioclase & K-feldspar & Calcite & Chlorite & $\begin{array}{l}\text { Illite } \pm \text { mus- } \\
\text { covite }\end{array}$ & Vivianite \\
\hline $5.2 \mathrm{~m}$ (soil) & 63 & 13 & - & 3 & 2 & 19 & - \\
$5.2-6.6 \mathrm{~m}$ (soil) & 64 & 13 & - & 8 & 9 & 6 & - \\
$\begin{array}{c}7.6-8.5 \mathrm{~m} \text { (sepa- } \\
\text { rated vivianite) }\end{array}$ & 27 & 9 & 3 & - & 11 & 20 & 30 \\
\hline
\end{tabular}

From 5.2 to $6.6 \mathrm{~m}$ the formation is mild gray in color, and homogeneous. It contains mollusk shells (both complete and fragmented ones) and sporadically fine mica lamellae in considerable quantity; the matrix contains carbonate in high amount. Based on the grain-size distribution (Table 1, No. ICE-113, 6.5-6.6 m), the dominant fraction is medium- and coarse-grained silt (70 $\mathrm{wt} \%)$; the proportion of the clayey fraction is less than $15 \mathrm{wt} \%$, and that of the (fine-grained) sand fraction is not more than $10 \mathrm{wt} \%$. According to Shepard's nomenclature (Shepard 1954), it can be classified as clayey silt. XRPD and thermal analytical studies show that the mineral constituents of the layer are quartz (64\%), plagioclase $(13 \%)$, calcite $(8 \%)$, chlorite $(9 \%)$, and illite \pm muscovite $(6 \%)$ (Table 2$)$.

Beneath $6.6 \mathrm{~m}$, the formation is relatively homogeneous; light grayish brown in color, fine laminated, and sporadically contains fine mica lamellae. Between 7.6 and $8.5 \mathrm{~m}$, it contains dark blue vivianite of earthy appearance and very low amount of carbonate.

Between 7.8 and $8.5 \mathrm{~m}$ fine (sulfate?) precipitation covers the formation. According to the grain-size distribution (No. ICE-113, 7.6-7.8, 7.8-8.0, 8.0-8.2, 8.2-8.4, and 8.4-8.5 m), the dominant fractions are medium- and fine-grained silt; the proportion of the clay fraction considerably decreased (ca. $10 \mathrm{wt} \%$ ), and the quantity of the sandy fraction is highly varying (from 8 to $25 \mathrm{wt} \%$ ). Due to the varying proportion of the fine-grained sand and clay fractions, they can be classified as sandy silt or clayey silt according to Shepard's nomenclature (Shepard 1954).

The separated vivianite material was studied by macroscopic, stereo microscopic scanning microscopic observations, thermal analysis (TG/DTG), and XRPD techniques. Macroscopic and stereo microscopic observations suggest that the vivianite dominantly appears along laminae of the finely layered matrix, as it were, "impregnates" it; subordinately, vivianite forms earthy aggregates. Back-scattered electron microscope image of the separated vivianite material shows the lamellae of the vivianite crystals grew on the grains of the formation and filled the intergranular space (Fig. 5). Thermal features of vivianite have not been understood in all details. Some studies suggest that temperature loss (together $25 \%$ loss of mass) due to one-step thermal decomposition occurs between 70 and $500{ }^{\circ} \mathrm{C}$ with a peak at about $150{ }^{\circ} \mathrm{C}$ (Ogorodova et al. 2017). In contrast, Földvári
(2011) suggests that vivianite loses its crystalline water through an endothermic reaction between 250 and $300{ }^{\circ} \mathrm{C}$; this author notes, however, that crystalline water may be removed in several steps, too. TG/DTG curves suggest that vivianite crystalline water is released in several steps (Fig. 7), which is in accordance with some former studies. Results of the XRPD study show that besides vivianite, the separated material contains some quartz, muscovite, chlorite, and feldspars, as well (Table 2; Fig. 8).

Hydro-chemical parameters and concentrations of some selected chemical constituents from the first and second aquifers are shown in Table 3. Comparing to the background, data indicate increased dissolved orthophosphate, sulfate,

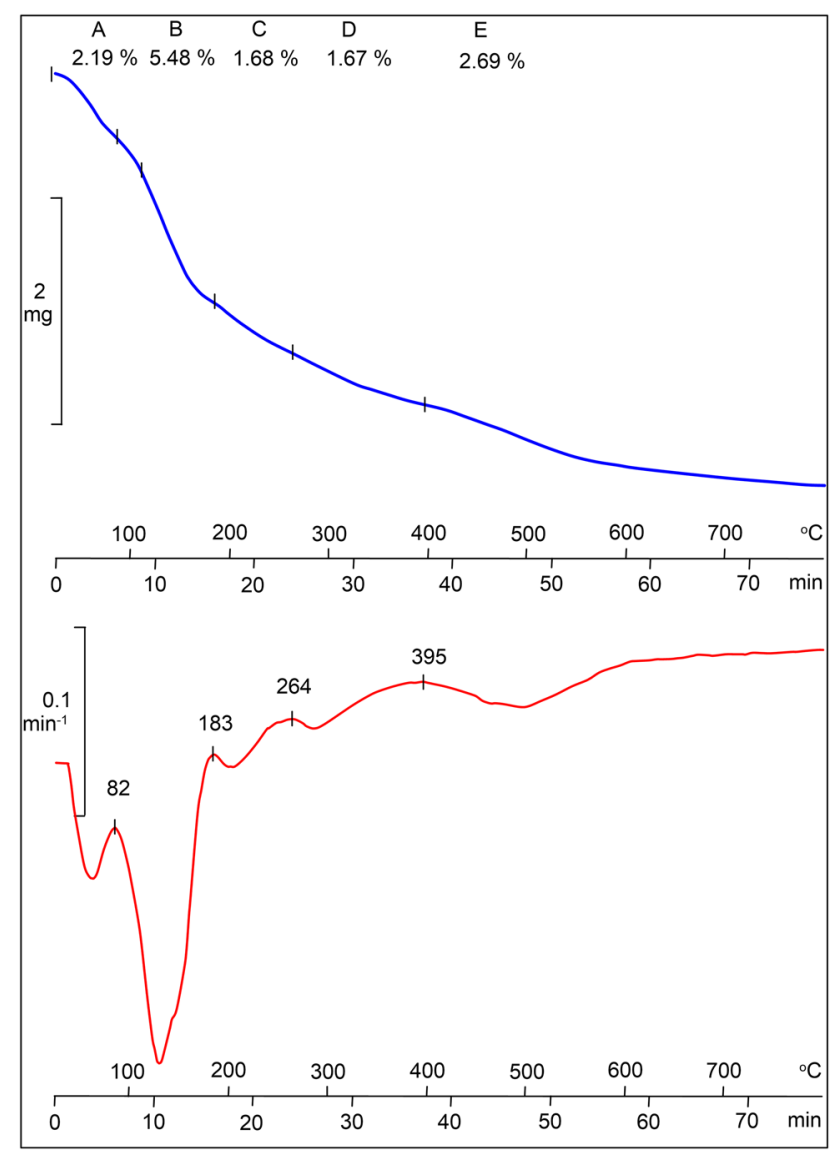

Fig. 7 TG/DTG curves of vivianite separated from the depth of 7.6$8.5 \mathrm{~m}$ 


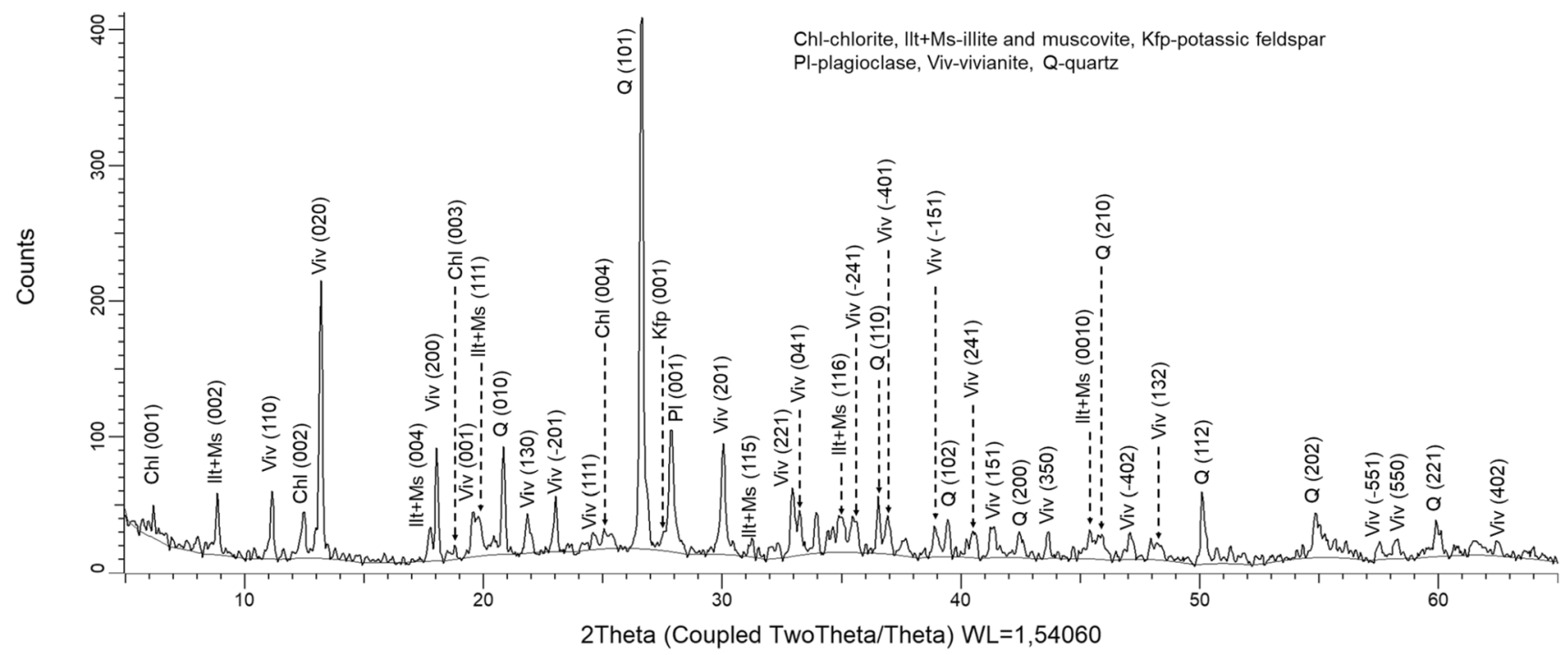

Fig. 8 X-ray powder diffraction diagram of the separated vivianite material taken from the depth of 7.6-8.5 m

Table 3 Summary of selected chemical constituent concentrations and physico-chemical parameters in samples from wells screened in the first and second aquifers

\begin{tabular}{|c|c|c|c|c|c|c|}
\hline & \multicolumn{3}{|l|}{ 1st aquifer } & \multicolumn{3}{|l|}{ 2nd aquifer } \\
\hline & pond & nearby ICE-113 & background & pond & nearby ICE-113 & background \\
\hline $\mathrm{PO}_{4}{ }^{3-}\left(\mathrm{mg} / \mathrm{dm}^{3}\right)$ & $10-40$ & $0.6(0.5-2.0)$ & $<0.5$ & $5-20$ & $0.4(0.1-1.0)$ & $<0.5$ \\
\hline $\mathrm{SO}_{4}{ }^{2-}\left(\mathrm{mg} / \mathrm{dm}^{3}\right)$ & $150-400$ & $50(30-100)$ & $<100$ & $100-270$ & $30(20-43)$ & $<50$ \\
\hline $\mathrm{pH}$ & $7.4-7.5$ & $7.4(7.3-7.6)$ & $7.0-7.5$ & $7.15-7.4$ & 7.4 & $6.5-7.5$ \\
\hline $\mathrm{Eh}(\mathrm{mV})$ & $20-180$ & 250 & $200-260$ & $80-90$ & 100 & $100-190$ \\
\hline $\mathrm{DO}\left(\mathrm{mg} / \mathrm{dm}^{3}\right)$ & $0.3-0.4$ & 0.5 & $0.5-2.0$ & $0.3-0.35$ & 0.25 & $0.25-0.4$ \\
\hline $\mathrm{NO}_{3}{ }^{-}\left(\mathrm{mg} / \mathrm{dm}^{3}\right)$ & $2-9$ & 1.6 & $1-10$ & $2-6$ & 0.8 & $<2$ \\
\hline $\mathrm{Fe}\left(\mathrm{mg} / \mathrm{dm}^{3}\right)$ & $1.5-3.5$ & 0.5 & $<1.0$ & $4-11$ & 1.5 & $1-3$ \\
\hline $\operatorname{Mn}\left(\mathrm{mg} / \mathrm{dm}^{3}\right)$ & $0.2-0.5$ & 0.3 & $0.5-2.0$ & $0.3-0.5$ & 0.5 & $<0.5$ \\
\hline $\mathrm{CO}_{3}{ }^{2-}\left(\mathrm{mg} / \mathrm{dm}^{3}\right)$ & $<1.0$ & $<1.0$ & $<1.0$ & $<1.0$ & $<1.0$ & $<1.0$ \\
\hline $\mathrm{HCO}_{3}^{-}\left(\mathrm{mg} / \mathrm{dm}^{3}\right)$ & $1600-4800$ & $350-600$ & $400-700$ & $1100-2600$ & $500-650$ & $500-650$ \\
\hline $\begin{array}{l}\text { General redox catego- } \\
\text { ries and processes }\end{array}$ & $\begin{array}{l}\text { Mixed (anoxic) } \\
\mathrm{NO}_{3}-\mathrm{Fe}^{3+} / \mathrm{SO}_{4}\end{array}$ & \multicolumn{2}{|c|}{ Mixed (oxic-anoxic) $\mathrm{O}_{2}-\mathrm{Fe}^{3+} / \mathrm{SO}_{4}$} & \multicolumn{3}{|c|}{ Mixed (anoxic) $\mathrm{NO}_{3}-\mathrm{Fe}^{3+} / \mathrm{SO}_{4}$} \\
\hline
\end{tabular}

Redox categories in the groundwater were identified by Jurgens et al. (2009)

iron, and $\mathrm{HCO}_{3}{ }^{-}$concentration, and decreased Eh values in both aquifers in the vicinity of the former sewage pond and well cluster No. ICE-113.

\section{Discussion}

As it was mentioned in the introduction, occurrence of vivianite in Hungary is common in terrestrial sediments characterized by reductive environments of high iron(II) and orthophosphate and low $\mathrm{S}^{2-}$ concentration of pore water, where $\mathrm{pH}$ and Eh conditions are also sufficient (Szakáll et al.
2005). The point is whether the geochemical features in the study area are adequate for the formation of vivianite.

\section{Chemical and physico-chemical conditions of groundwater}

In the area of the chemical plant, the "basal clay" forming the floor of the first aquifer was exposed by several drills; however, vivianite has not been found in it. The chemical composition of the pore water in the "basal clay" has not been known; however, chemical composition and physical-chemical features of the first and second aquifers are well studied. Chemical constituent and physico-chemical 
parameter data listed in Table 3 suggest extremely high orthophosphate concentration in the groundwater within a distance of $150 \mathrm{~m} \mathrm{NE}$ of the well cluster No. ICE-113 in the first aquifer (2-6 $\mathrm{m}$ beneath the surface) with a concentration range between 10 and $40 \mathrm{mg} / \mathrm{dm}^{3}$ and with a maximum value of $80 \mathrm{mg} / \mathrm{dm}^{3}$, while the average orthophosphate concentration for the whole area of the plan is as low as $0.5 \mathrm{mg} / \mathrm{dm}^{3}$ (Table 3). Because of the limitation of available data $(\mathrm{n}<10)$, it is difficult to determine obvious trends by time series analysis (e.g., Mann-Kendall test); it can be stated, however, that in the studied time span orthophosphate concentration in the first aquifer increased in the area of the sewage pond, while no trend could be experienced in the monitoring well cluster No. ICE-113. Moreover, in the vicinity of the sewage pond increased orthophosphate concentration $\left(5-20 \mathrm{mg} / \mathrm{dm}^{3}\right)$ could be detected even in the second aquifer, which possibly shows an increasing trend. Simultaneously to the orthophosphate concentration, sulfate concentration also increased in the first and the second aquifers at the sewage pond (150-400 and $100-270 \mathrm{mg} / \mathrm{dm}^{3}$, respectively); time series of the concentrations suggest increasing-possibly increasing trend, excepting the well cluster No. ICE-113, where a decreasing trend is noticed. This decrease in sulfate can be in relationship with diluting processes at plume margin, and it can be a consequence of increasing sulfate reduction following the iron reduction in the Terminal Electron Accepting Process sequence; as a consequence, $\mathrm{HS}^{-}$is formed from the dissolved orthophosphate (Miao et al., 2012). The sulfate reaction can take place under circumneutral $\mathrm{pH}$ conditions with considerable $\mathrm{H}^{+}$consumption; or due to microbiological activity by requisition of organic carbon or $\mathrm{H}_{2}$, which finally results in $\mathrm{pH}$ decrease (Nriagu 1972; Postma 1981; Heiberg et al. 2012; Egger et al. 2015; Rothe et al. 2014, 2016).

Accordingly, values of Eh and dissolved oxygen have decreased in the sewage pond area (particularly, in the first aquifer), while contents of dissolved nitrate and total iron have multiplied. In the area of the former sewage pond ORP values measured in the wells installed into the first aquifer after purging have varied between -365.8 (calculated Eh: $-151 \mathrm{mV}$ ) and $-65.5 \mathrm{mV}$ (calculated Eh: $149 \mathrm{mV}$ ) (with an average of $-205 \mathrm{mV}$ ORP and of $8 \mathrm{mV} \mathrm{Eh}$ ), for the last 5 years (2014 and 2018); while in a monitoring well near the site of well cluster No. ICE-113 screened in the first aquifer the ORP values have ranged from -82.5 (calculated Eh: $133 \pm 5 \mathrm{mV}$ ) to $142.6 \mathrm{mV}$ (calculated Eh: $359 \pm 5 \mathrm{mV}$ ) (with an average of $22 \mathrm{mV}$ ORP and of $238 \mathrm{mV}$ Eh). The average Eh distribution map calculated from the ORP results of the first aquifer clearly shows that redox potential on the site of the former pond is definitely low even nowadays, which indicates reductive conditions, as it was mentioned previously. This reductive condition tends to change just in the environment of the well cluster No. ICE-113 as it is indicated by ORP, as well as Eh values ranging from 0 to $50 \mathrm{mV}$ and from 200 to $300 \mathrm{mV}$. The ORP values vary from -50 to $-150 \mathrm{mV}$ (Eh of $80-190 \mathrm{mV}$ ) in the second aquifer and are also lower than the background in the surroundings of the sewage pond.

A USGD Excel sheet (Jurgens et al. 2009) was used for identifying redox processes in the groundwater. Unfortunately, however, the redox state of iron and manganese was not analyzed, and dissolved sulfur was analyzed as sulfate, therefore, certain forms and the total amount of sulfides is not known. It is obvious, however, that under the sewage pond there are mixed (anoxic) redox conditions in the first aquifer, while mixed (oxic-anoxic) conditions are characteristic for the well cluster No. ICE-113 and the background; then again, everywhere in the second aquifer mixed (anoxic) redox conditions can be detected. Therefore, groundwater data clearly show that in the area of and some meters surrounding the pond physical and chemical conditions dramatically changed compared to the wider environment, and it may have an effect on geochemical and biochemical processes in the area. Distribution maps (Fig. 9) show that the concentration of dissolved oxygen is depleted not only at the pond but at the northern part of the study area, too. Possibly, this depletion has not been the result of the decomposition of the deposed organic material. It is supported by the fact that, parallel to a decrease in DO, an increase in dissolved total iron can be detected in the pond area, which suggests increasing microbial Fe reduction. This phenomenon can also be observed in the second aquifer; although it is not so well-marked there.

Groundwater in the first aquifer is neutral ( $\mathrm{pH} 7.0-7.4)$; however, slightly alkaline (7.5-7.8) in the site of the former pond and at the well cluster No. ICE-113. In the second aquifer, $\mathrm{pH}$ is $7.2-7.3$ in the site of the former pond, and it is 7.3 at the well cluster No. ICE-113.

The $\mathrm{pH}$ values do not show a noticeable anomaly, which suggests that the matter released from the pond did not induce an essential modification in the acid-base system. It is important since the formation of vivianite is highly $\mathrm{pH}$ regulated (Liu et al. 2018). Accordingly, XRPD detected vivianite with higher degree of crystallization, which is characteristic for vivianite formed at about $\mathrm{pH} 7$ (Liu et al. 2018). However, $\mathrm{pH}$ values of water in the vicinity of the well cluster No. ICE-113 and the pond are slightly increased, which suggests intensification of sulfate reduction. Nitrate concentrations are elevated in both aquifers, but regarding the first aquifer dissolved nitrate input comes from other sources, as well.

The concentration of dissolved $\mathrm{HCO}_{3}{ }^{-}$is particularly important since it fundamentally influences vivianite formation. As Table 3 shows at the well cluster No. ICE-113 $\mathrm{HCO}_{3}{ }^{-}$concentrations of the first and second aquifer are 

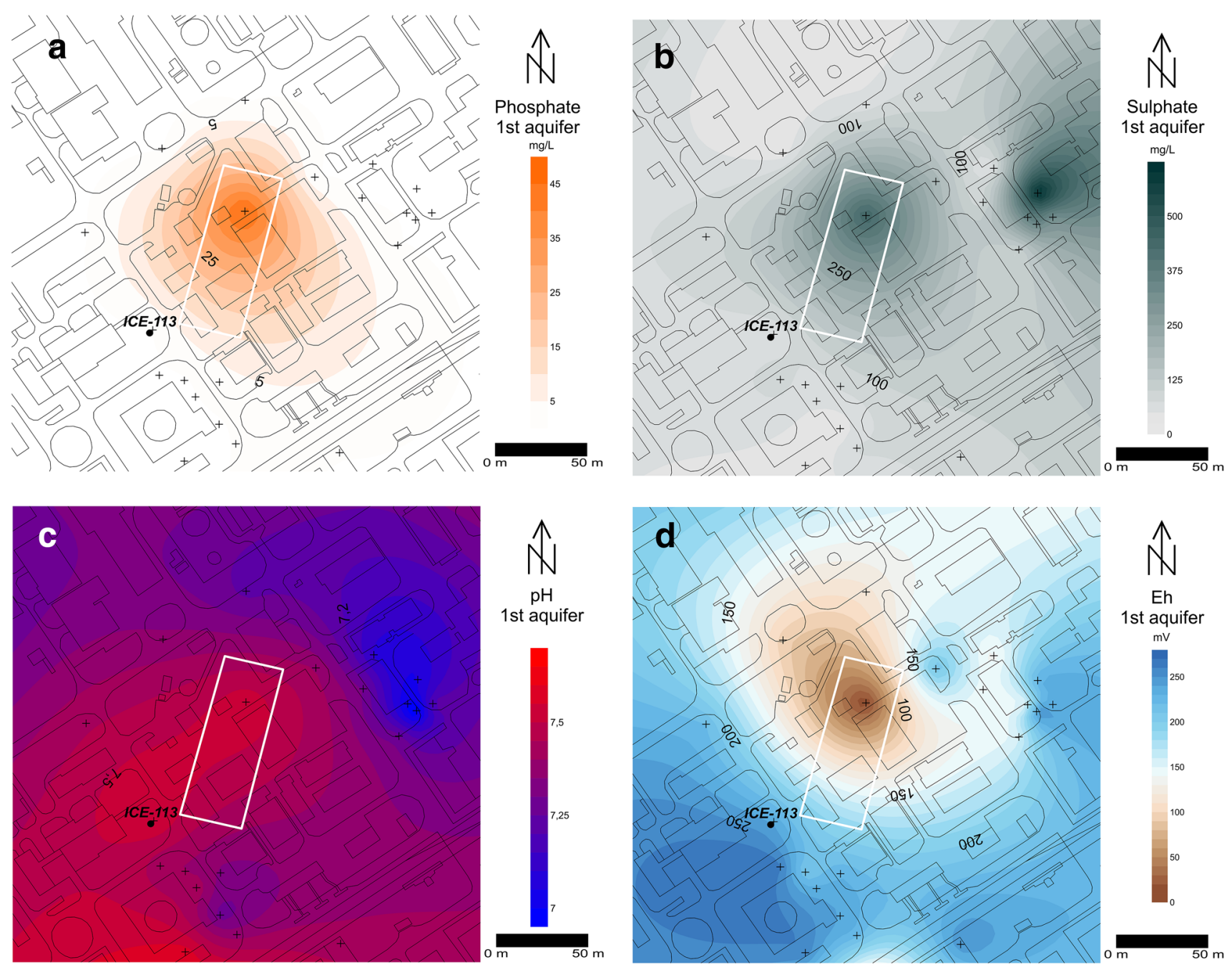

Fig. 9 Distribution maps based on the average concentrations and values of phosphate, sulfate, $\mathrm{pH}$, Eh, $\mathrm{DO}$, nitrate, iron and manganese in the first and second aquifers in the vicinity of the pond

equal to background values; however, they are multiplied under the sewage pond.

In our opinion, the high orthophosphate content of the groundwater is the result of the decomposition of the biomass deposed in the late 1950s and the early 1960s, and this assumption is supported by the map of the dissolved orthophosphate distribution in the groundwater (Fig. 9). In this period, the amount of the processed and then deposited plant litter might be several thousand tons per year. The depth of the sewage pond is unknown; however, the increased $\left(5-20 \mathrm{mg} / \mathrm{dm}^{3}\right)$ orthophosphate concentration in the second aquifer suggests that there could be a direct communication between the aquifers.

\section{Transportation of orthophosphate}

The next point is whether the dissolved orthophosphate could filtrate from the pond to the site if the well cluster
No. ICE-113 is under natural hydrogeological conditions characteristic for the study area. The upper part of the vivianite-bearing "basal clay" (which can be found from 4.0 to $9.0 \mathrm{~m}$ below the surface) can be regarded as clayey fine- and medium-grained silt, while its lower part is silt. The $K$ filtration coefficient of the "basal clay" was calculated using the grain-size distribution curve; this method is widely accepted in hydrogeological-environmental geological practice; however, it should be carefully applied. Several mathematical formulae have been published for estimating filtration coefficient using grain-size distribution curves; however, these can be applied for sediments possessing a given distribution and sorting. We used Devlin's Excel with a VBA code file (Devlin, 2015). According to the calculations, characteristic filtration coefficient values are $8.2 \times 10^{-9}-1.4 \times 10^{-8} \mathrm{~m} / \mathrm{s}$ and $1.0 \times 10^{-8}-1.8 \times 10^{-8} \mathrm{~m} / \mathrm{s}$ for the more clayey upper, and for the sandy and vivianite-bearing lower part of the 

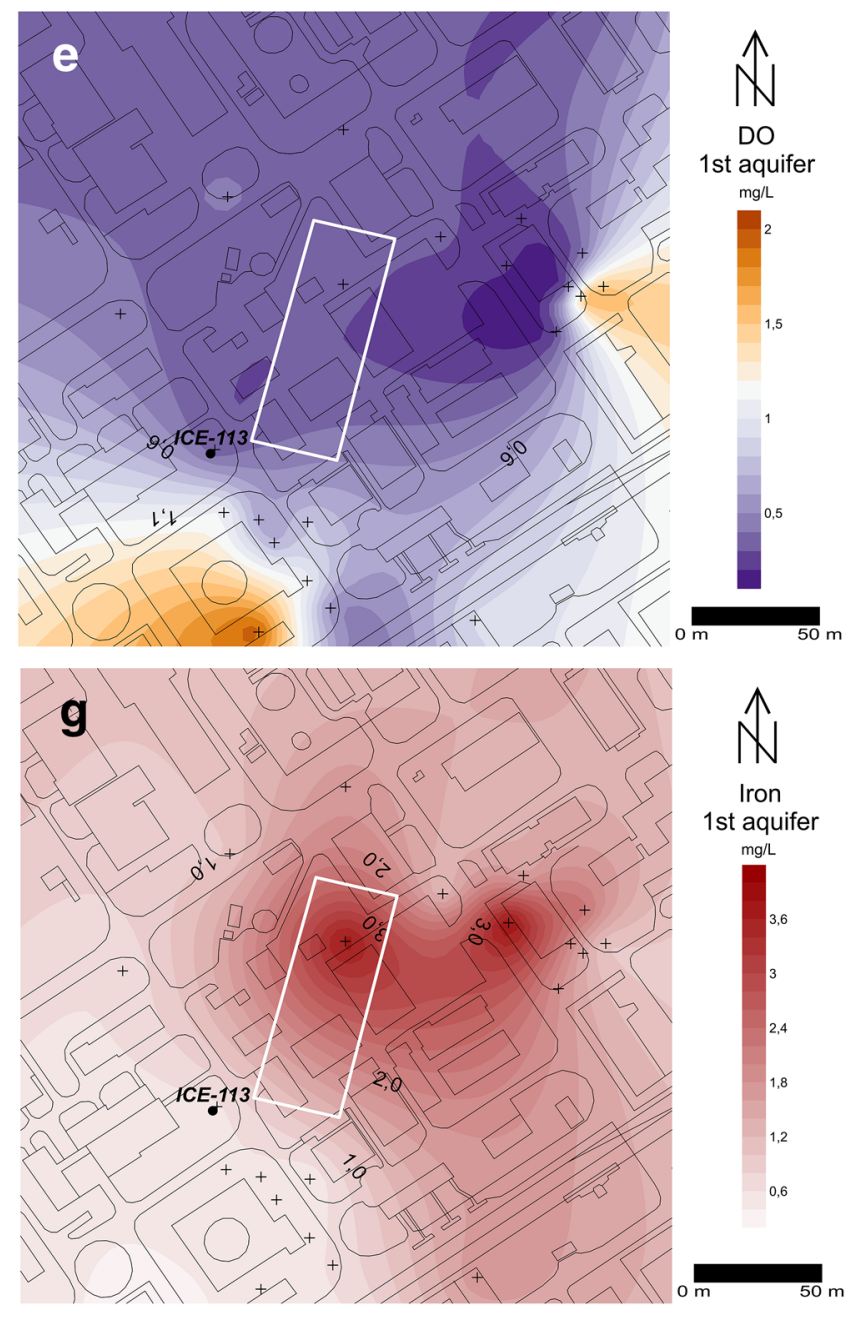

Fig. 9 (continued)

"basal clay", respectively. Therefore, the "basal clay" can be regarded as a leaky confining bed.

Unfortunately, site-specific data for the specific yield of "basal clay" is not known; however, according to Singhal and Gupta (2010) effective porosity (or specific yield which can be regarded as the same) for silt may range from 5 to $20 \%$. Due to high uncertainties, a conservative approach (advection) was applied to predict the fate and transport processes of the dissolved orthophosphate. Considering the calculated horizontal hydraulic gradient of the first aquifer (0.004), the above-mentioned filtration coefficient, and the 5-20\% effective porosity values characteristic for silts, we can use the formula

$v=\frac{K \mathrm{~d} h}{n \mathrm{~d} l}$,

where $v$ is the seepage velocity of the groundwater in the "basal clay" as a leaky confined bed; $K$ is the hydraulic conductivity; $n$ is the specific storage; and $\mathrm{d} h / \mathrm{d} l$ is the hydraulic
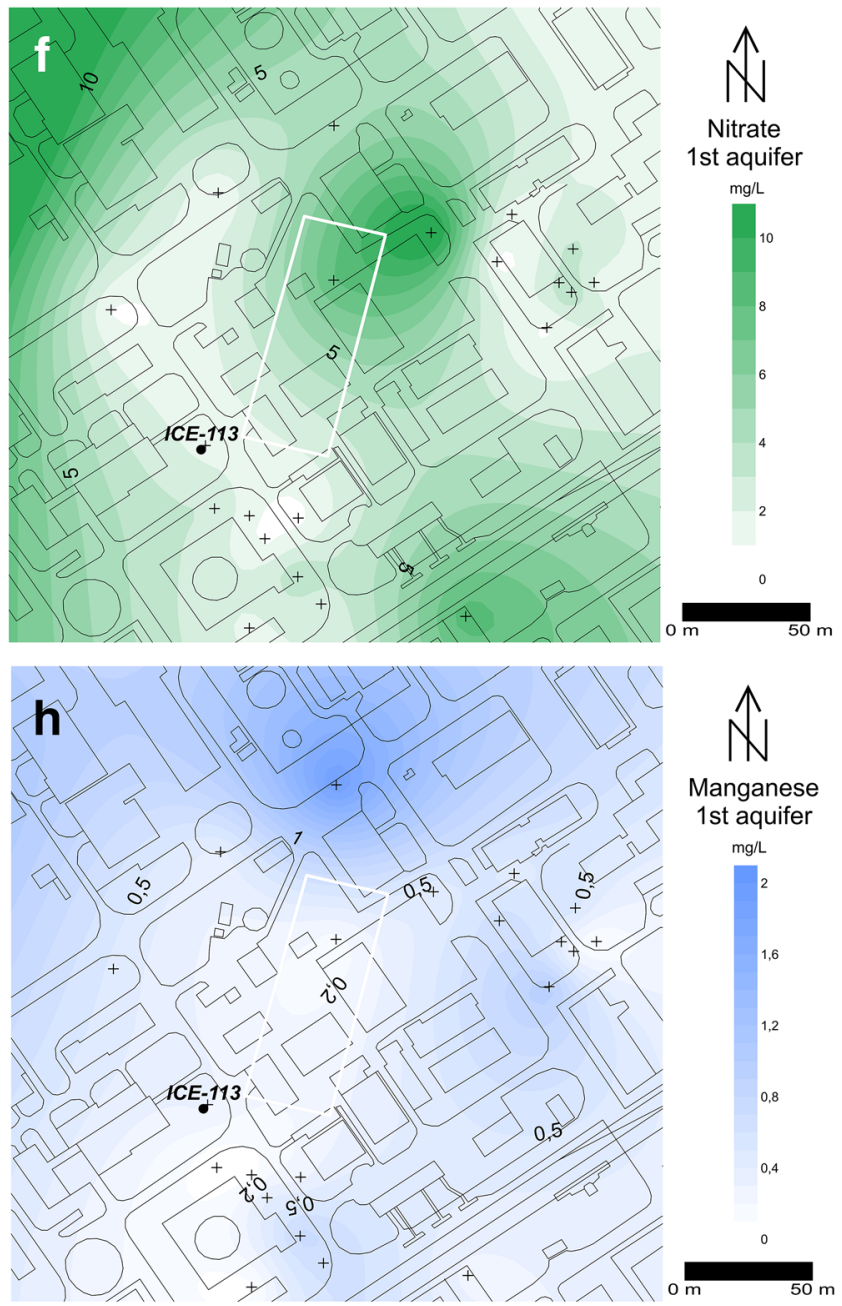

gradient. According to the calculation, during 50 years propagation of the groundwater could range from 3 to $22 \mathrm{~m}$ in the lower, silty part of the "basal clay"; considering that the well cluster No. ICE-113 traversing the vivianite-bearing layer is located $15 \mathrm{~m}$ of the margin of the former pond, it can be stated the dissolved orthophosphate could be advectively transported by groundwater from the former pond to the site of the drilling.

\section{Origin of iron}

Formation of vivianite requires proper quantity of iron in the pore water. In the first and the second aquifer, the concentration of the total dissolved iron is about $1 \mathrm{mg} / \mathrm{dm}^{3}$ in the background, while definitely increased beneath the sewage pond in the first aquifer $\left(1.5-3.5 \mathrm{mg} / \mathrm{dm}^{3}\right)$ and especially in the second aquifer $\left(4-11 \mathrm{mg} / \mathrm{dm}^{3}\right)$. Temporal change in dissolved iron in the underground water suggests intensification of iron reduction, which is not a simple facilitating 

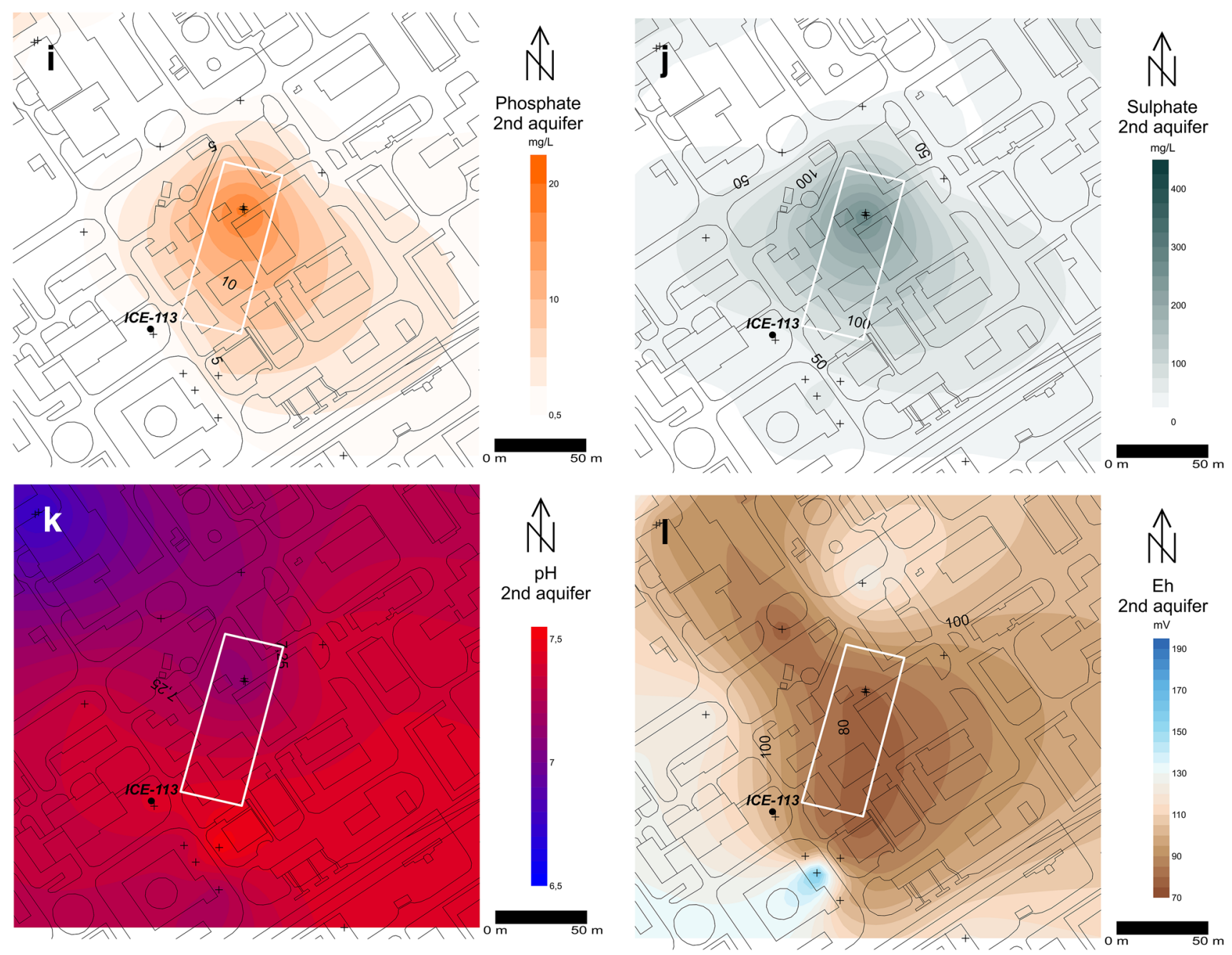

Fig. 9 (continued)

but indispensable factor of vivianite formation. Considerable amount of reduced sulfur in the system may inhibit this process because it favors the formation of iron sulfides. Precipitation of vivianite is possible under a relatively narrow range of $\mathrm{pH}$-Eh conditions $(5-9 \mathrm{pH}$ and from +200 to $-200 \mathrm{mV}$ Eh) (Lemos et al. 2007; Dill and Techmer 2009); moreover, low S:Fe ratio also favors this process (Rothe et al. 2016). Depending $\mathrm{HCO}_{3}{ }^{-}$activity $\left(\log _{\mathrm{aHCO} 3} \geq 3\right.$ ) siderite may also form at the expense of vivianite, quasi competing with it for the dissolved $\mathrm{Fe}^{2+}$ (Dill and Techmer 2009); however, XRPD analysis did not detect siderite in our samples. This experience can be explained by low kinetics of formation and growth of siderite (which is also characteristic for vivianite) (Postma 1981), and particularly by the fact that $\mathrm{HCO}_{3}{ }^{-}$concentration in the well cluster No. ICE-113 is almost equal to the background concentration. A considerable increase in $\mathrm{HCO}_{3}{ }^{-}$activity may favor formation of siderite at the expense of that of vivianite (Dill and Techmer 2009). In the surroundings of the well cluster No.
ICE-113 the concentrations of $\mathrm{HCO}_{3}{ }^{-}$are favorable for the formation of vivianite, while toward the pond, because of multiplied $\mathrm{HCO}_{3}{ }^{-}$concentrations, formation of siderite can be expected.

As a source of reduced $\mathrm{Fe}$, chlorite and micas should also be considered. On the altered crystal edges and surfaces exposing the octahedral sites occupied by $\mathrm{Fe}^{2+}$, the action of dissolved phosphate in basic $\mathrm{pH}$ may induce dissolution of cations and subsequent precipitation through crystallization of a stable product. In such a situation, the action of orthophosphate in basic solution is initiating the reaction on chlorite crystallites, supported by the BSE observations, that vivianite is mostly formed on the surface of chlorite rich aggregates.

Another geological factor may also contribute to vivianite formation. It is highly possible that the water level in the pond was considerably higher than the static water level in the first aquifer; therefore, mobile inorganic components, such as orthophosphate, radially spread from the pond. As 

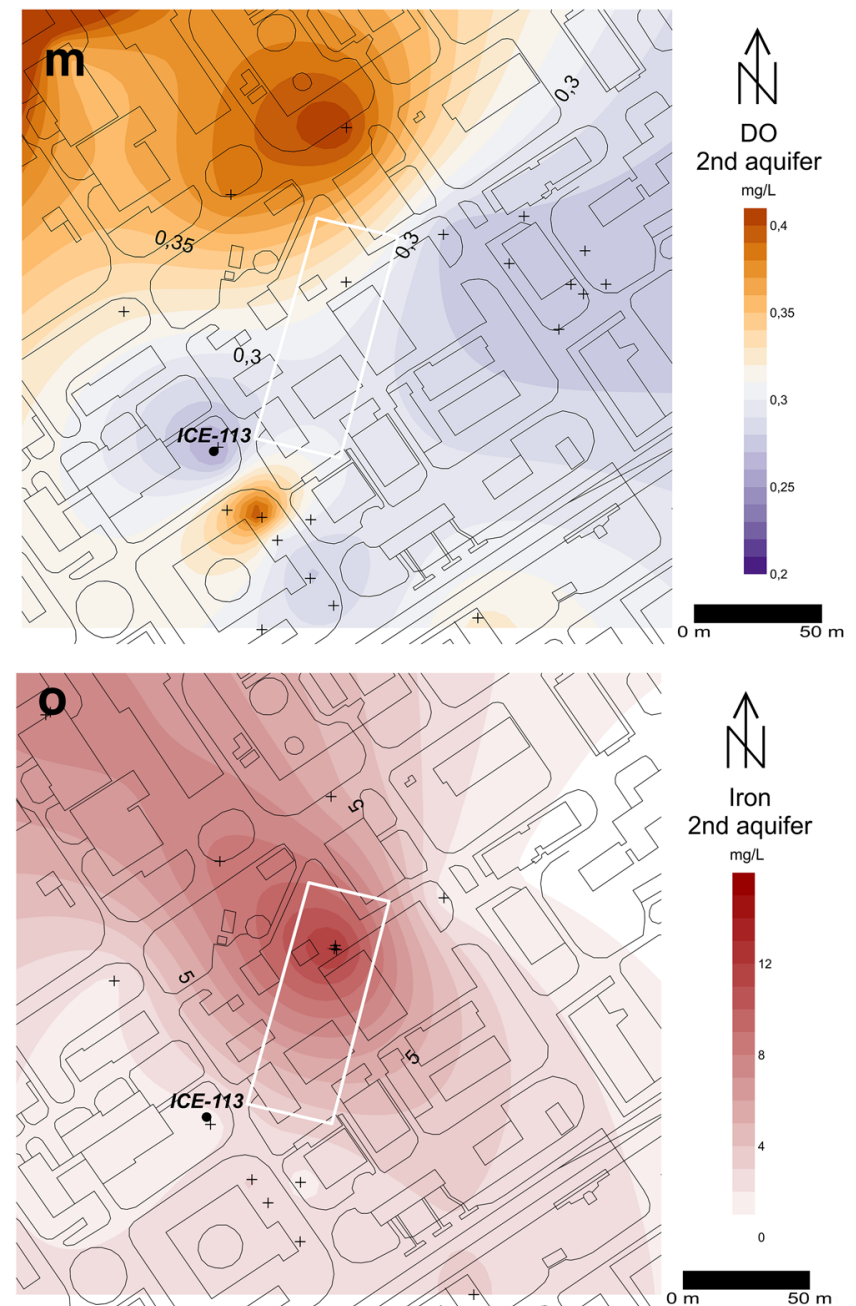

Fig. 9 (continued)

Fig. 10 shows the upper surface of the "basal clay" can be dominantly found at $90.0-90.5 \mathrm{~m}$ a.s.l. and slopes to the south, however, here and there it is $1.0-1.5 \mathrm{~m}$ higher. This kind of elevation of the "basal clay" occurs at the well cluster ICE-113. East of the pond, however, the first aquifer is much thicker, and physical, chemical, and lithological conditions characteristic for this bed do not allow the formation of vivianite.

\section{Conclusions}

Vivianite formation in soils and clayey sediments requires several particular circumstances, such as proper $\mathrm{pH}$ and redox conditions, high dissolved $\mathrm{PO}_{4}{ }^{3+}$ and $\mathrm{Fe}^{2+}$ as well as low $\mathrm{HCO}_{3}{ }^{-}$and $\mathrm{HS}^{-}$in pore water. These factors are basically influenced by the character of microbial activity, iron-hydroxides, and iron-oxyhydroxides, as well as sorption features of clay minerals. Based on the available
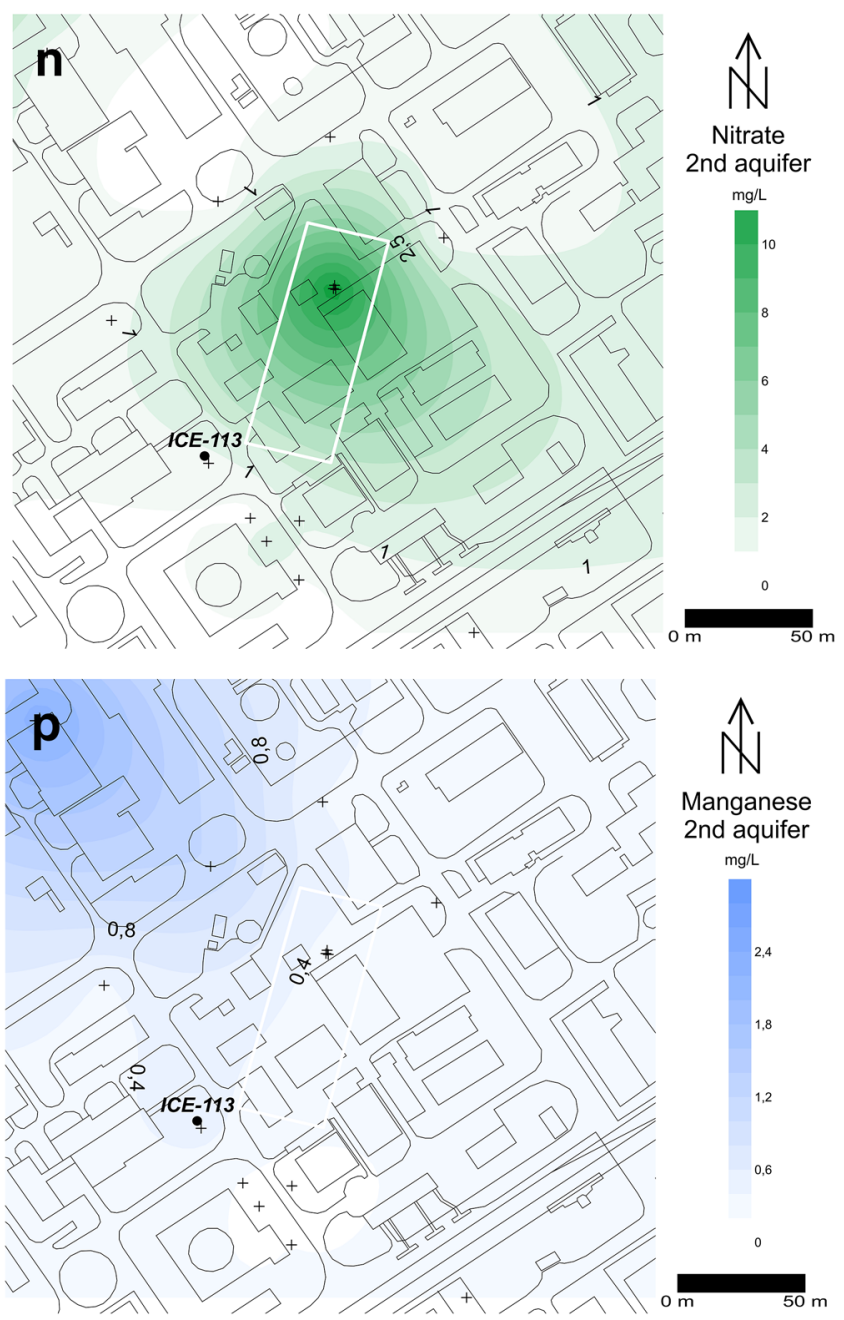

geological data, the formation of vivianite in the study area is the result of the fixation of phosphate released by the decomposition of organic by-product material which had been deposed here for decades. Consequently, its mineralogical classification could be ambiguous. According to the recommended definition of the International Mineralogical Association (IMA) Commission on New Minerals and Mineral Names (CNMMN), a mineral is a normally crystalline element or chemical compound formed by the action of geological processes (Nickel 1995); moreover, anthropogenic substances should not be considered minerals even if they were formed by geological processes, although the borderline between natural and man-made (i.e. mineral or non-mineral) substances can be unclear in many cases (Nickel and Grice 1998). The studied vivianite seems to be a simple case in this respect: its crystals were formed of natural substances in natural geological medium by action of geological processes. On the other hand, however, high phosphate concentration at the site is 
Fig. 10 The topography of the top of the "basal clay" layer

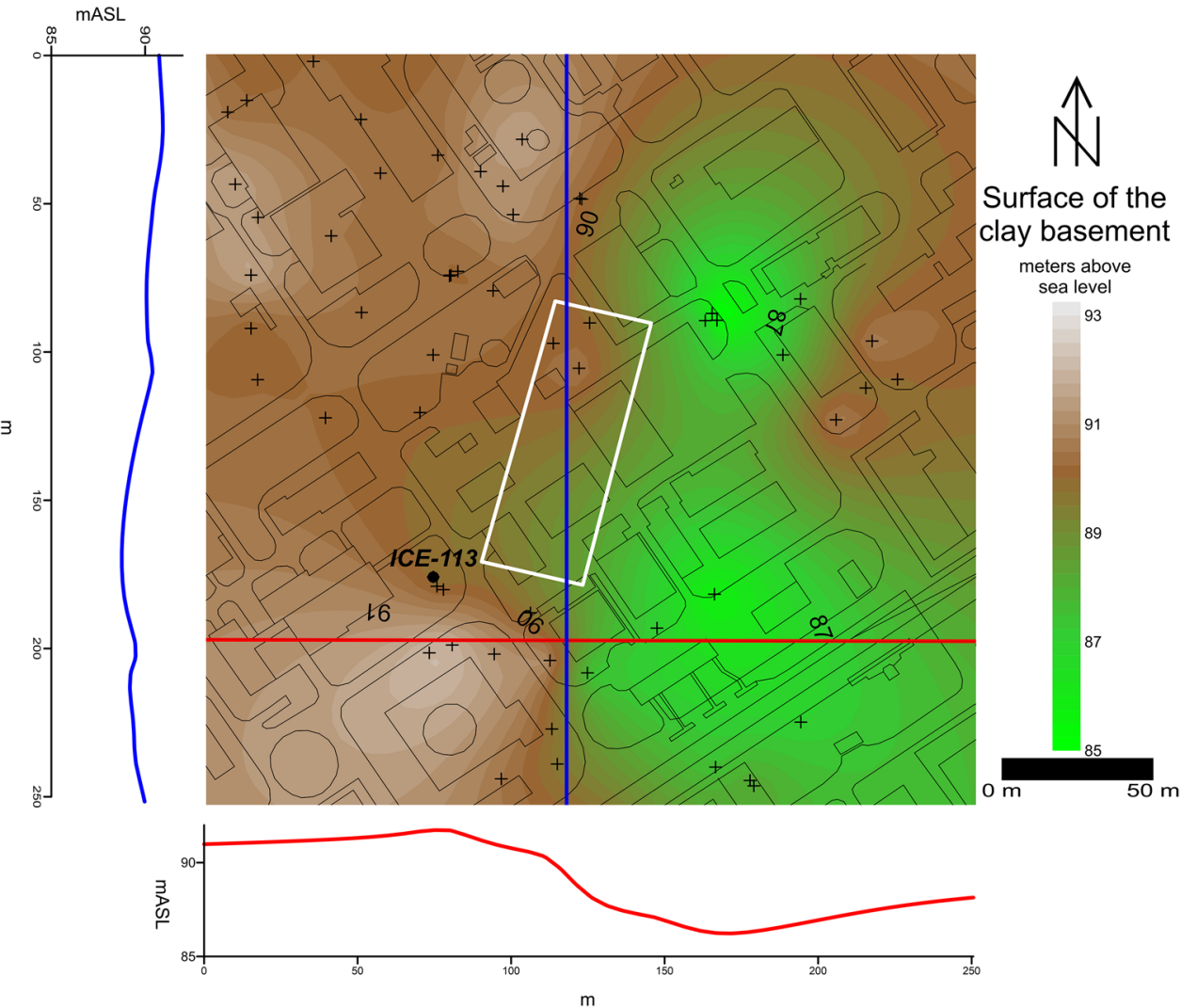

due to human action, and also human intervention made the accelerated horizontal seepage possible; therefore, although vivianite formed by natural mineralization, it was induced by hidden human intervention. The present situation is one of those special cases, where anthropogenic mineral formation is revealing underground processes related to long-term industrial seepage; moreover, our results suggest that the gray zone between 'natural' and 'anthropogenic' minerals may be wider than it has been generally supposed.

Acknowledgements The described article was carried out as part of the EFOP-3.6.1-16-2016-00011 "Younger and Renewing University-Innovative Knowledge City-institutional development of the University of Miskolc aiming at intelligent specialization" project implemented in the framework of the Szechenyi 2020 program. The realization of this project is supported by the European Union, cofinanced by the European Social Fund. The authors also thank Richard William McIntosh (University of Debrecen) for revising the English text.

Author contributions CÁ: thermal analysis, mapping and interpreting the results, compiling the text for publication. PL: field measurements, collecting samples and data. KF: XRD analysis and interpreting the XRD results. SS: SEM-EDS analysis and interpreting the SEM-EDS results. RP: interpreting the results, compiling the text for publication.
Funding Open access funding provided by University of Debrecen. The described article was carried out as part of the Human Resource Development Operational Programme (EFOP)-3.6.1-16-2016-00011 "Younger and Renewing University-Innovative Knowledge CityInstitutional development of the University of Miskolc aiming at intelligent specialization" project implemented in the framework of the Szechenyi 2020 program. The realization of this project is supported by the European Union, co-financed by the European Social Fund.

\section{Declarations}

Conflict of interest There is no conflict of intersts or competing inteterest.

Availability of data and material The relevant data are published in the paper.

Code availability Not applicable.

Open Access This article is licensed under a Creative Commons Attribution 4.0 International License, which permits use, sharing, adaptation, distribution and reproduction in any medium or format, as long as you give appropriate credit to the original author(s) and the source, provide a link to the Creative Commons licence, and indicate if changes were made. The images or other third party material in this article are included in the article's Creative Commons licence, unless indicated otherwise in a credit line to the material. If material is not included in the article's Creative Commons licence and your intended use is not permitted by statutory regulation or exceeds the permitted use, you will 
need to obtain permission directly from the copyright holder. To view a copy of this licence, visit http://creativecommons.org/licenses/by/4.0/.

\section{References}

Azam HM, Finneran KT (2014) $\mathrm{Fe}^{(\mathrm{III})}$ reduction-mediated phosphate removal as vivianite $\left(\mathrm{Fe}_{3}\left(\mathrm{PO}_{4}\right)_{2} \cdot 8 \mathrm{H}_{2} \mathrm{O}\right)$ in septic system wastewater. Chemosphere 97:1-9

Balázs A, Matenco L, Magyar I, Horváth F, Cloetingh S (2016) The link between tectonics and sedimentation in back-arc basins: new genetic constraints from the analysis of the Pannonian Basin. Tectonics 35:1526-1559

Devlin JF (2015) HydrogeoSieveXL: an Excel-based tool to estimate hydraulic conductivity from grain size analysis. Hydrogeol $\mathrm{J}$ 23:837-844

Devlin JF, Schillig PC (2017) HydrogeoEstimatorXL: an Excel-based tool for estimating hydraulic gradient magnitude and direction. Hydrogeol J 25:867-875

Dill HG, Techmer A (2009) The geogene and anthropogenic impact on the formation of per descensum vivianite-goethite-siderite mineralization in Mesozoic and Cenozoic siliciclastic sediments in SE Germany. Sediment Geol 217:95-111

Dodd J, Large DJ, Fortey NJ, Milodowski AE, Kemp S (2000) A petrographic investigation of two sequential extraction techniques applied to anaerobic canal bed. Environ Geochem Health 22:281-296

Dodd J, Large DJ, Fortey NJ, Kemp S, Styles M, Wetton P, Milodowski $\mathrm{AE}$ (2003) Geochemistry and petrography of phosphorus in urban canal bed sediment. Appl Geochem 18:259-267

Egger M, Jilbert T, Behrends T, Rivard C, Slomp CP (2015) Vivianite is a major sink for phosphorus in methanogenic coastal surface sediments. Geochim Cosmochim Acta 169:217-235

Földvári M (2011) Handbook of thermogravimetric system of minerals and its use in geological practice. Geological Institute of Hungary, Budapest, $180 \mathrm{p}$

Franyó F (1992) Isopach map of Quaternary sediments in Hungary (1:500000). Hungarian Geological Survey, Budapest (in Hungarian)

Frossard E, Bauer JP, Lothe F (1997) Evidence of vivianite in $\mathrm{FeSO}_{4}$-flocculated sludges. Water Res 31:2449-2454

Gábris G, Nádor A (2007) Long-term fluvial archives in Hungary: response of the Danube and Tisza rivers to tectonic movements and climatic changes during the Quaternary: a review and new synthesis. Quat Sci Rev 26:2758-2782

Gächter R, Müller B (2003) Why the phosphorous retention of lakes does not necessarily depend on the oxygen supply to their sediment surface? Limnol Oceanogr 48:929-933

Goslar T, Ralska-Jasiewiczowa M, van Geel B, Łącka B, Szeroczyńska K, Chróst L, Walanus A (1999) Anthropogenic changes in the sediment composition of Lake Gościąż (central Poland), during the last 330 yrs. J Paleolimnol 22:171-185

Grizelj A, Bakrač K, Horvat M, Avanić R, Hećimović I (2017) Occurrence of vivianite in alluvial quaternary sediments in the area of Sesvete (Zagreb, Croatia). Geol Croat 70:41-52

Gunnars A, Blomquist S, Johansson P, Andresson C (2002) Formation of $\mathrm{Fe}^{(\mathrm{III})}$ oxyhydroxide colloids in freshwater and brackish seawater with incorporation of phosphate and calcium. Geochim Cosmochim Acta 66:745-758

Harangi S (2001) Neogene to quaternary volcanism of the carpathianpannonian region - a review. Acta Geol Hung 44:223-258
Heiberg L, Koch CB, Kjaergaard C, Jensen HS (2012) Hansen HCB (2012) vivianite precipitation and phosphate sorption following iron reduction in anoxic soils. J Environ Qual 41:938-949

Hudson-Edwards KA, Houghton S, Taylor KG (2008) Efficiencies of As uptake from aqueous solution by a natural vivianite material at $4^{\circ} \mathrm{C}$. Mineral Mag 72:429-431

Islam FS, Lawson M, Pythgoe PR, Wogelius RA, Thinnapann V, Lloyd JR, Charnock JM, Polya DA (2007) Adsorption of As ${ }^{(\mathrm{III})}$ and $\mathrm{As} \mathrm{s}^{\mathrm{(V)}}$ onto vivianite: evaluation as a sink for arsenic in Bengalian aquifers. Geochim Cosmochim Acta 71:A432

Jámbor Á (2001) Quarternary. In: Haas J (ed) Geology of Hungary. Eötvös University Press, Budapest, pp 265-278

Jurgens BC, McMahon PB, Chapelle FH, Eberts SM (2009) An Excel ${ }^{\circledR}$ workbook for identifying redox processes in ground water. U.S. Geological Survey Open-File Report 2009-1004, 8 p

Kázmér M (1990) Birth, life and death of the Pannonian Lake. Palaeogeogr Palaeoclimatol 79:171-188

Kiss T, Hernesz P, Sümeghy B, Györgyövics K, Gy S (2015) The evolution of the Great Hungarian Plainfluvial systeme-Fluvialprocesses in a subsiding area from the beginning of the Weichselian. Quat Int 388:142-155

Kleeberg A, Köhler A, Hupfer M (2012) How effectively does a single or continuous iron supply affect the phosphorus budget of aerated lakes? J Soils Sediments 12:1593-1603

Lehmkuhl F, Bösken J, Hošek J, Sprafke T, Marković SB, Obreht I, Hambach U, Sümegi P, Thiemann A, Steffens S, Lindner H, Veres D, Zeeden C (2018) Loess distribution and related Quaternary sediments in the Carpathian Basin. J Maps 14:661-670

Lemos VP, da Costa ML, Lemos RL, de Faria MSG (2007) Vivianite and siderite in lateritic iron crusts: an example of bioreduction. Quim Nova 30:36-40

Liu J, Cheng X, Qi X, Li N, Tian J, Qiu B, Xua K, Qu D (2018) Recovery of phosphate from aqueous solutions via vivianite crystallization: thermodynamics and influence of $\mathrm{pH}$. Chem Eng J 349:37-46

McGowan G, Prangnell J (2006) The significance of vivianite in archaeological settings. Geoarchaeology 21:93-111

Miao Z, Brusseau ML, Carroll KC, Carreón-Diazconti C, Johnson B (2012) Sulfate reduction in groundwater: characterization and applications for remediation. Environ Geochem Health 34:539-550

Muehe EM, Morin G, Scheer L, Pape PL, Esteve I, Daus B, Kappler A (2016) Arsenic $^{(\mathrm{V})}$ incorporation in vivianite during microbial reduction of $\operatorname{arsenic}^{(\mathrm{V})}$-bearing biogenic $\mathrm{Fe}^{(\mathrm{III})}$ (oxyhydr)oxides. Environ Sci Technol 50:2281-2291

Nádor A, Thamó-Bozsó E, Magyari Á, Babinszki E (2007) Fluvial responses to tectonics and climate change during the LateWeichselian in the eastern part of the Pannonian Basin (Hungary). Sediment Geol 202:174-192

Nickel EH (1995) The definition of a mineral. Can Mineral 33:689-690

Nickel EH, Grice JD (1998) The IMA Commission on new minerals and mineral names: procedures and guidelines on mineral nomenclature, 1998. Can Mineral 36:913-926

Nriagu JO (1972) Stability of vivianite and ion-pair formation in the system $\mathrm{Fe}_{3}\left(\mathrm{PO}_{4}\right), 2{ }_{-} \mathrm{H}_{\mathrm{P}} \mathrm{O} 4{ }_{-} \mathrm{H} 2 \mathrm{O}$. Geochim Cosmochim Acta 36:459-470

Nriagu JO, Dell CI (1974) Diagenetic formation of iron phosphates in recent lake sediments. Am Mineral 59:934-946

O'Connell DW, Jensen MM, Jakobsen R, Thamdrup B, Andersen TJ, Kovacs A, Hansen HCB (2015) Vivianite formation and its role in phosphorus retention in Lake Ørn, Denmark. Chem Geol 409:42-53

Ogorodova L, Vigasina M, Mel'chakova L, Rusakov V, Kosova D, Ksenofontov D, Bryzgalov I (2017) Enthalpy of formation of 
natural hydrous iron phosphate: vivianite. J Chem Thermodyn 110:193-200

Postma D (1981) Formation of siderite and vivianite and the pore-water composition of the recent bog sediment in Denmark. Chem Geol 31:225-244

Rónai A, Moldvay L (1966) Explanatory book of the geological map series of Hungary (1:200000) L-34-IV Debrecen. Geological Institute of Hungary, Budapest (in Hungarian)

Rónai A (1985) Quaternary Geology of the Great Hungarian Plain. Geologica Hungarica series geologica 21. Geological Institute of Hungary, Budapest (in Hungarian)

Rothe M, Frederichs T, Eder M, Kleeberg A, Hupfer M (2014) Evidence for vivianite formation and its contribution to long-term phosphorus retention in a recent lake sediment: a novel analytical approach. Biogeosciences 11:5169-5180

Rothe M, Kleeberg A, Hupfer M (2016) The occurrence, identification and environmental relevance of vivianite in waterlogged soils and aquatic sediments. Earth Sci Rev 158:51-64

Rouzies D, Millet JMM (1993) Mössbauer study of synthetic oxidized vivianite at room temperature. Hyperfine Interact 77:19-28

Shepard FP (1954) Nomenclature based on sand-silt-clay ratios. J Sediment Petrol 24:151-158

Singhal BBS, Gupta RP (2010) Applied hydrogeology of fractured rocks, 2nd edn. Springer, New York
Szakáll S, Gatter I, Szendrei G (2005) Minerals of Hungary. Kőország Kiadó, Budapest (in Hungarian)

Taylor KG, Boult S (2007) The role of grain dissolution and diagenetic mineral precipitation in the cycling of metals and phosphorus: a study of a contaminated urban freshwater sediment. Appl Geochem 22:1344-1358

Thinnappan V, Merrifield CM, Islam FS, Polya DA, Wincott P, Wogelius RA (2008) A combined experimental study of vivianite and $A s^{(\mathrm{V})}$ reactivity in the $\mathrm{pH}$ range $2-11$. Appl Geochem 23:3187-3204

Vymazal J (2007) Removal of nutrients in various types of constructed wetlands. Sci Total Environ 380:48-65

Zelenka T, Balogh K, Kozák M, Pécskay Z, Ravasz C, Kiss J, Püspöki Z (2004) Buried Neogene volcanic structures in Hungary. Acta Geol Hung 47:177-219

Publisher's Note Springer Nature remains neutral with regard to jurisdictional claims in published maps and institutional affiliations. 